\title{
University partnerships for co-designing and co-producing urban sustainability
}

\author{
Authors \\ Gregory Trencher ${ }^{\star}$, Xuemei Bai ${ }^{\star \star}$, James Evans ${ }^{\star \star \star}$, Kes McCormick ${ }^{\star \star \star \star}$, Masaru Yarime ${ }^{\star \star \star \star \star}$ \\ *University of Tokyo: Graduate School of Frontier Sciences \\ ** Australian National University: Fenner School of Environment and Society \\ ${ }^{* * *}$ University of Manchester: School of Environment, Education and Development \\ ****Lund University: International Institute for Industrial Environmental Economics \\ ***** University of Tokyo: Graduate School of Public Policy; and University College London: \\ Department of Science, Technology, Engineering and Public Policy.
}

Main contact: trencher@sustainability.k.u-tokyo.ac.jp

\section{Forthcoming in Global Environmental Change Accepted 29 June, 2014}

Refer to official journal website for final printed version and citation information 


\begin{abstract}
Universities are playing an increasingly central role in advancing sustainability at the local, regional and national scale through cross-sector collaborations. Accompanying the launch of Future Earth, interest is mounting in the co-design and co-production of knowledge and solutions for advancing global sustainability, particularly in urban areas. Place-based university partnerships appear as particularly significant vehicles for enacting co-design and co-production in the context of urban sustainability. However, the nature and role of these partnerships are not well understood, in part due to the absence of systematic analyses across multiple cases. To fill this gap, the objectives of this paper were to conduct a largescale international survey focusing on university partnerships for urban sustainability in industrialised Europe, Asia and North America to 1) determine defining features such as focus areas, geographical scales, mechanisms, actors and motivations, and 2) identify commonly encountered drivers, barriers and potential impacts.
\end{abstract}

Results indicate that partnerships most typically target energy, buildings, governance and social systems, unfold at local or city-scales, and involve collaborations with local or regional government. Our analysis shows that potential outcomes of university initiatives to co-design and co-produce urban sustainability are not limited to knowledge and policy. They encompass new technological prototypes, business and new socio-technical systems, in addition to transformations of the built and natural environment. Findings also suggest that individual partnerships are making strong social, environmental and sustainability impacts, with less evidence of economic contributions. Strategies are required to enhance project management and ensure that projects address contrasting priorities and time horizons in academia and local government. Implications for policy include findings that targeted funding programmes can play a key role in fostering partnerships. Measures are also required to challenge academic norms and incentive structures that, in some cases, hinder university efforts to engage in place-based initiatives to co-design and co-produce urban sustainability.

Keywords: co-design; co-production; sustainability; university partnerships; stakeholder collaborations; urban. 


\section{Introduction}

The grand sustainability challenges of our time such as climate change, food, water and resource security, pollution, environmental degradation and other socio-economic concerns are symptomatic of systematic failures (Rotmans and Loorbach, 2008). Tackling such problems requires fundamental re-configuration of interconnected technological, environmental, social, economic and political systems and processes (McCormick et al., 2013; O'Brian et al., 2012). Cities are loci where many of these problems coexist and such systems and processes intertwine (Grimm et al., 2008). With the majority of humanity concentrated in urban areas, cities are widely regarded as central arenas in the "battle" for global sustainability (Clark, 2003; Kamal-Chaoui and Robert, 2009; Nevens et al., 2013). However, creating societal transformations towards greater sustainability surpasses the resources or expertise of any single player or organisation (Kania and Kramer, 2011). The advancement of urban sustainability therefore requires collaboration between academia, government, industry and civil society (Clarke and Holiday, 2006; Yarime et al., 2012).

With the ten-year Future Earth initiative officially launched at the UN Conference on Sustainable Development (Rio+20), the co-design of research agendas and co-production of scientific knowledge and societal transformations towards sustainability has been advocated as a new model of science (Future Earth, 2013; Mauser et al., 2013). Universities are well placed to assume a central role in the co-design and co-production of knowledge and tools for societal transformations towards sustainability with diverse external stakeholders from industry, government and civil society. Universities generate scientific, technological and social innovation and educate next generation leaders (Cortese, 2011; M'Gonigle and Starke, 2006), link differing sectors of expertise and mediate across these networks (Arbo and Benneworth, 2007; Cash et al., 2003; Sedlacek, 2013), amass research funds and donations, hold extensive urban real estate assets (Perry and Wiewel, 2005), and enjoy a high level of societal trust from their non-profit status and commitment to the public good (Bok, 2003; Stephens et al., 2008).

Cross-sector university partnerships for urban sustainability appear to be flourishing across the world (Trencher, 2014; Trencher et al., 2013; 2014) heralding a significant development in the functions of the modern research university. Yet the relative newness of this trend has so far prevented a thorough understanding of the defining attributes, mechanisms by which university actors engage with and transform society, and the extent to which partnerships reflect principles of co-design and co-production. Scholars (Hoover and Harder, 2014; Karatzoglou, 2013; Stephens et al., 2009) observe that the literature on this topic is dominated by single or small sets of case studies, mostly descriptive, and the absence of robust analytical frameworks. To date there has been no systematic comparison and statistical analysis across a large number of cases. 
In this study, to offer a multi-national perspective moving beyond Anglophone countries, we conducted a large-n survey on place-based university partnerships for co-producing, knowledge, tools and societal transformations to advance urban sustainability. This survey of industrialised nations in Europe, Asia and North America has two core objectives: 1) to determine key attributes (urban systems, geographical scale of activities, partners and stakeholders involved, motivations and mechanisms) of collaborative efforts to co-design and co-production of urban sustainability, and 2) to identify commonly encountered drivers, barriers and potential impacts. By doing so, this paper builds the empirical foundations for interpreting the worldwide emergence of university partnerships for urban sustainability. Also offering a critical perspective of various tensions and driving forces, our study suggests potential strategies and policies for fostering the formation and effectiveness of university partnerships to co-design and co-produce knowledge and solutions for advancing urban sustainability. 


\section{Theoretical perspectives on university partnerships for urban sustainability}

Experimentation is crucial for advancing sustainability (Koenig and Evans, 2013). University partnerships are typically experimental due to research activities and an innovative, exploratory nature. Systems innovation literature has taken a high interest in the importance of 'sustainability experiments' for trialling novel configurations of technology, social and institutional arrangements (Bai et al., 2009; 2010; Berkhout et al., 2010). This body of scholarship defines sustainability experiments as "planned initiatives that embody a highly novel socio-technical configuration likely to lead to substantial (environmental) sustainability gains" (Berkhout et al., 2010). In addition to technological advancement, sustainability experiments can potentially facilitate learning on social and human dimensions of sustainability (Brown, 2003). As no individual societal player possesses the knowledge or resources to single-handedly bring about socio-technical transformations (Kania and Kramer, 2011), sustainability experiments must entail the mobilisation of knowledge, capabilities and resources from various societal sectors (i.e. industry, government, academia and civil society). Sustainability experiments resonate with the principles of co-design and co-production, which are attracting renewed interest as potential drivers of societal transformations towards sustainability (Mauser et al., 2013). A key challenge for emerging global-level research programmes such as Future Earth is to determine how specific geographical locations can function as strategic sites for knowledge production and socio-technical experiments for triggering societal transformations towards greater sustainability.

In this context, interest is mounting in collaborative innovation models for urban sustainability-particularly those targeted at neighbourhoods or cities. An emerging conceptual lens to describe the application of sustainability experiments to specific urban zones is the notion of a 'living urban laboratory' (Bulkeley et al., 2011; Evans and Karvonen, 2011; Evans and Karvonen, 2014). Corresponding with the idea of creating protected 'niches' of innovation (Geels, 2002), complexity and uncertainty means that initiatives to create societal transformations towards sustainability should start small before up-scaling and exporting elsewhere. Empirical evidence suggests that local government actors around the world are increasingly willingly to engage in such cross-sector experiments to carry out sustainability and climate commitments (Bai, 2007; Bulkeley et al., 2014; Castan Broto and Bulkeley, 2013). Fuelling a rising interest in experimental approaches to urban governance are failures by national or international level political frameworks to shift local and regional level development trajectories towards sustainability (Hoffman, 2011; McCormick et al., 2013; Orr, 2013). For experiments involving scientific knowledge production with academics, a key driver appears to be a broader transition in science towards pragmatic epistemologies and research agendas with greater societal relevance (Evans and Karvonen, 2011; Gibbons, 1999; Lubchenco, 1988). Often described as a move from 'mode 1' to 'mode 2 ' type knowledge production, scientific knowledge is increasingly produced in application and in 
response to stakeholder needs (Etzkowitz, 2002; Nowotny et al., 2001). This shift reflects a growing awareness that greater innovation can result from collaboration and open networks (Gorman, 2010; Schaffers and Turkama, 2012; Shrum et al., 2007) with both horizontal and vertical linkages (Bai et al., 2009).

Universities can play a crucial role in such experiments. Scholars have documented partnerships where university and societal actors collaboratively use urban areas as test-beds for emerging technologies in energy, construction and transport (Evans and Karvonen, 2011; Keyson et al., 2013; König, 2013; Lienin et al., 2004; 2005; Molnar et al., 2011; Trencher et al., 2013; 2014; Yarime et al., 2012). Others (De Kraker et al., 2013; Valkering et al., 2013) describe a process of mutual learning where researchers, government authorities and citizens exploit social innovation at the local scale to spur wider societal transitions by sharing experiences across trans-border networks. Some (Horrigan, 2014; Pothukuchi, 2011) document the collaborative process of creating social value and increasing resiliency by stimulating local food consumption and creating new urban food networks, whilst others (Evans and Karvonen, 2014, Trencher et al., 2014) describe cross-sector attempts to combat socio-economic decline through real-estate development and efforts to spur low-carbon, knowledge-driven growth.

The global proliferation of cross-sector university partnerships for sustainability also reflects the rise of the 'knowledge economy'. Intimate university-industry relations in many partnerships appear fuelled by the spread of the 'entrepreneurial university' (Etzkowitz et al., 2000, Etzkowitz, 2002) and technology transfer activities (Mowery, 2007), a role often normatively framed as a 'third mission' for the university (Vorley and Nelles, 2008). As knowledge-producing institutions, universities are now widely positioned as engines of economic growth (Yusuf and Nabeshima, 2008; OECD, 2007). Against such a backdrop, partnerships for urban sustainability are often laden with expectations - or promises-for economic outputs and tangible contributions to regional innovation systems. Also important is the influence of government research funding priorities on the structure and role of partnerships. Many state actors have explicitly linked the pursuit of urban sustainability to the creation and trial of new technologies, thereby privileging fields such as engineering and the natural sciences over the humanities, social sciences and non-technical approaches to sustainability.

Despite widespread acceptance that urban sustainability requires cooperation across societal sectors, calls for heightened collaboration between the university and societal stakeholders, 'useful' research agendas and concrete outcomes are not without criticism. Some fear that emphasis on immediate and instrumental research may threaten the autonomy of the university and its ability to foster innovation and critical thinking (Bell, 2007; Demeritt, 2005). Others are raising concerns about the rise of patenting and the conception-some say "neoliberal" (Canaan and Shumar, 2011) - of scientific knowledge as a tradable rather than 
public good (Nelson, 2004; Mowery, 2007). Others still contend that no matter how well intentioned, urban sustainability experiments are inevitably political (Karvonen et al., 2014), vested with certain interests (Bulkeley et al., 2014) and often propelled by corporations viewing innovation for sustainability chiefly in technical or economic-rather than socialterms (Hodson and Marvin, 2009). 


\section{Methods and analytical frameworks}

The empirical approach of this study may be summarised in three steps: 1) sample collection, 2) development of analytical tools, and 3) application of these tools to the sample. The combination of a large- $n$ sample and quantitative application of analytical frameworks has been previously demonstrated in the context of non-academic cross-sector sustainability partnerships by numerous scholars including Bai et al. (2010), Castan Broto and Bulkeley (2013), Hoffman (2011) and Pattberg et al. (2012). If applied to a study of university partnerships for urban sustainability, such approaches can generate a rich array of statistical and macro-level data and provide a valuable overview of the global landscape. Here we seek to contribute to this body of literature by applying similar approaches for understanding specifically university-driven urban sustainability partnerships.

\subsection{Sample collection}

We collected samples based on the following four criteria. That is, any completed or ongoing partnership: a) aiming to advance the sustainability of a particular urban location or region (of any geographical scale) or societal system of that area; b) involving formal or informal collaborations with any combination of stakeholders from government, industry, civil society and academia; c) initiated, coordinated or lead by university actors; and d) involving societal interventions on a predominantly off-campus location, region or set of external stakeholders. Our geographical focus is on industrialised nations in Europe, Asia and North America and specifically those qualifying as 'high-income' economies as defined by the World Bank (i.e. GNP per capita in 2012 > US\$12,615.). This yields an international perspective encompassing differing cultural, linguistic, political, technological and academic contexts, yet ensures consistency regarding socio-economic and political conditions. Sample collecting unfolded from June 2011 to November 2013, with efforts made to achieve a regional balance. Search activities were conducted predominantly in English, but also in French and Japanese. This choice of languages was constrained to those understood by the lead author. Although not representative of all major world languages, inclusion of French and Japanese proved highly useful in overcoming restraints of data availability in English. It thus allowed us to consider key trends in various countries not commonly represented in Anglophone studies.

Table 1 shows a list of major search methods.

A total of 70 cases were identified (see Appendix $\mathbf{1}$ for a summary of each), with the geographical distribution shown in Figure 1. The vast majority of cases are concentrated in Europe and North America. Possibly reflecting higher tendencies for university actors in these regions to form cross-sector sustainability initiatives, this distribution is certainly influenced by the possibility that many partnerships in non-English speaking Asia (such as Korea, Hong Kong and Taiwan) were invisible to our study for linguistic reasons. 
Table 1 Methods for identification of cases

\begin{tabular}{|c|c|}
\hline Search method & Specific technique \\
\hline Internet searches & $\begin{array}{l}\text { 1. Systematic searches with combinations of the following keywords (in English, French } \\
\text { and Japanese) with Google and Yahoo search engines: 'city/country name', } \\
\text { 'sustainable', 'low-carbon', 'climate', 'partnership', 'collaboration', 'university', 'corridor', } \\
\text { 'smart', 'city', 'urban laboratory' etc. } \\
\text { 2. Searches through key databases including: } \\
\text { - government funding bodies } \\
\text { - sustainability organisations and research institutes (both public and private) }\end{array}$ \\
\hline Document review & Scan of academic literature, press articles and sustainability organisation publications. \\
\hline $\begin{array}{l}\text { Communication with } \\
\text { peers }\end{array}$ & $\begin{array}{l}\text { Participation in numerous academic conferences related to sustainability. In addition, } \\
\text { informal (oral) and formal (email) information requests to colleagues in diverse fields } \\
\text { related to sustainability for names/details of suitable partnerships. }\end{array}$ \\
\hline $\begin{array}{l}\text { Communication with } \\
\text { experts }\end{array}$ & $\begin{array}{l}\text { Email requests for names/details of suitable partnerships sent to university sustainability } \\
\text { offices, research institutes and outreach offices in research universities (mostly in top } \\
200 \text { of Shanghai Jiao Tong Academic Ranking of World Universities). Requests also } \\
\text { sent to regional development agencies, local government and national/global } \\
\text { sustainability networks. }\end{array}$ \\
\hline
\end{tabular}

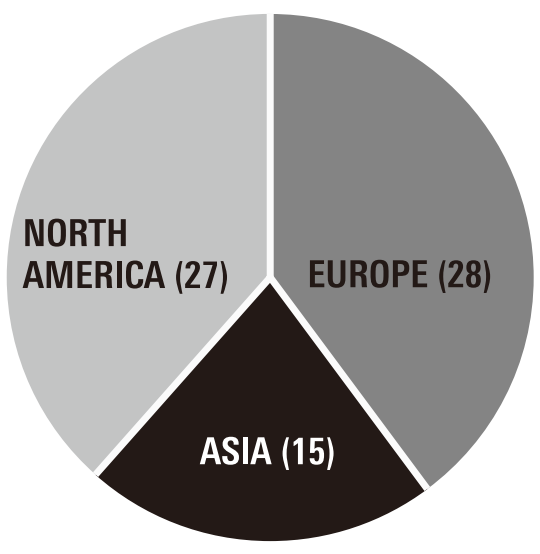

Figure 1 Geographical distribution of sample pool $(n=70)$

\subsection{Analytical tool development}

The 70 cases identified for this study have been scrutinised from three aspects 1) key characteristics, patterns and commonalities across regions, 2) commonly encountered barriers and drivers, and 3) functioning, effectiveness and impacts of individual partnerships. The first is addressed by a tool summarised in Table 2, based on analytical frameworks created and explained in previous studies of the author (Trencher et al., 2013; 2014). The design of these six-tiers of enquiry was aided by previous studies from Bai et al. (2010), Bulkeley and Castan Broto (2012), Castan Broto and Bulkeley (2013) and Pattberg et al. (2012). 
Table 2 Summary of six-level framework

(After: Trencher et al., 2013; 2014)

1. Urban system (what?)

- $\quad$ Built environment

- Transportation

- Energy and heating/cooling

- Economy, employment or industrial production

- Natural environment or green spaces

- Food, agriculture or forestry

- Water

- Solid waste

- Governance and planning

- Human and social systems

2. Scale of target area (where?)

- Local/neighbourhood

- City/town

- Regional/state

- National

- Trans-border

3. Internal actors (who?)

- Faculty/researchers

- Administration

- Students

- $\quad$ Bridging organisations

4. External actors (who?)

- Local/regional government

- $\quad$ State/national government

- $\quad$ Civic society

- Other academic institutions

- Large or multi-national corporation

- Small-medium enterprise

5. Motivation (why?)

- Missional

- Funding

- Scientific/scholarly

- Social contribution/community relations

- Developmental/strategic

- Entrepreneurial

6. Societal engagement modes (how?)

- Knowledge management

- $\quad$ Governance and planning

- Technology transfer or economic development

- Technical demonstrations and experiments

- Reform of built and natural environment

- Socio-technical experiments

To examine commonly encountered drivers and barriers, a second analytical tool was developed (see Table 3). Identification of these factors was achieved through a process of both inductive and deductive reasoning. That is, a set of commonly reported conditions affecting cross-sector partnerships was identified in the literature (Fadeeva, 2004; Hanleybrown et al., 2012, Kania and Kramer, 2011; Lozano, 2006; The Royal Society, 2006; Schaffers and Turkama, 2012; Zilahy and Huisingh, 2009) in addition to case studies on various university partnerships for urban sustainability (Evans and Karvonen, 2014; Lienin et al., 2004, 2005; Pothukuchi, 2011; Valkering et al., 2013). In parallel, they also came from insights generated in a total of 31 interviews (both telephone and in person) with various 
university actors and stakeholders, representative of nine partnerships across the three geographical regions.

Table 3. Framework for drivers and barriers

\begin{tabular}{|c|c|}
\hline Drivers & Barriers \\
\hline \multicolumn{2}{|l|}{ Internal factors } \\
\hline \multicolumn{2}{|c|}{$\begin{array}{l}\text { Synergy (i.e. magnified effect of cross-sector Lack of unity and harmony } \\
\text { participation) }\end{array}$} \\
\hline Strong leadership & Poor leadership or management \\
\hline University policy & $\begin{array}{l}\text { Traditional academic incentive systems and } \\
\text { norms }\end{array}$ \\
\hline \multirow[t]{3}{*}{ Co-ordination support } & Communication difficulties \\
\hline & Time restraints \\
\hline & Technical barriers \\
\hline \multicolumn{2}{|l|}{ External factors } \\
\hline External funding & $\begin{array}{l}\text { External funding (i.e. availability, length and } \\
\text { amount) }\end{array}$ \\
\hline Government policy & $\begin{array}{l}\text { Socio-cultural and institutional conditions (i.e. } \\
\text { locked-in lifestyles, low environmental } \\
\text { awareness, poor socio-economic conditions, } \\
\text { lack of institutional capacity etc.) }\end{array}$ \\
\hline $\begin{array}{l}\text { Societal 'need' } \\
\text { Positive societal forces (i.e. progressive or } \\
\text { environmentally aware society, strong culture } \\
\text { of collaboration and innovation etc.) }\end{array}$ & $\begin{array}{l}\text { Lack of external support and interest } \\
\text { (i.e. lack of interest in academic research or } \\
\text { collaboration with universities etc.) }\end{array}$ \\
\hline
\end{tabular}

To understand and assess impacts and the effectiveness of partnerships, a third analytical tool was developed. This consists of a simple self-evaluation framework adapted from a set of guidelines used by the United Nations Development Programme (UNDP, 2009), originally developed by the Organisation for Economic Co-operation and Development (OECD, 1991) for appraising individual development projects. In the UNDP (2009) evaluation framework, it is recommended that project evaluation efforts consider the following dimensions: relevance, effectiveness, efficiency, sustainability (i.e. non-normative definition, physical ability to continue after initial aid period) and impact. This adapted framework is condensed into Table 4 below. 
Table 4 Summary of evaluation framework

\begin{tabular}{|c|c|}
\hline Area & Focus/indicators \\
\hline \multicolumn{2}{|l|}{ Effectiveness } \\
\hline Synergy & $\begin{array}{l}\text { Does the participation of different actors and sectors (e.g. } \\
\text { universities, government, industry and citizens) have a positive } \\
\text { effect on the partnership and was their presence necessary to } \\
\text { achieve the goals of the partnership? }\end{array}$ \\
\hline Function & $\begin{array}{l}\text { Do the various partners, stakeholders and sectors involved in } \\
\text { the partnership successfully carry out their expected roles and } \\
\text { contribution? }\end{array}$ \\
\hline Effectiveness & $\begin{array}{l}\text { Is the partnership on track to achieving its initial objectives, or } \\
\text { for a finished partnership, has it successfully achieved its initial } \\
\text { objectives? }\end{array}$ \\
\hline \multicolumn{2}{|l|}{ Efficiency } \\
\hline Efficiency & $\begin{array}{l}\text { Are resources and inputs such as money, time, people and } \\
\text { materials converted efficiently to results? }\end{array}$ \\
\hline \multicolumn{2}{|l|}{ Impacts } \\
\hline Economic & $\begin{array}{l}\text { For example: } \\
\text { - Stimulation of economic activities } \\
\text { - Creation of employment or a new product/business/service } \\
\text { - Increase of industrial or business performance and efficiency } \\
\text { - Increase of regional competitiveness and vitality }\end{array}$ \\
\hline Environmental & $\begin{array}{l}\text { For example: } \\
\text { - Improvement of sustainability, environmental impacts or } \\
\text { resiliency of target area/city/region or business and industry } \\
\text { activity in that area } \\
\text { - Improvement of infrastructure and/or built or natural } \\
\text { environment } \\
\text { - Improved management of infrastructure and/or the built or } \\
\text { natural environment }\end{array}$ \\
\hline Societal & $\begin{array}{l}\text { For example: } \\
\text { - Improvement of social, political or cultural conditions } \\
\text { - Improved liveability and quality of life } \\
\text { - Improved public awareness or engagement in sustainability } \\
\text { or environmental issues }\end{array}$ \\
\hline Overall sustainability & $\begin{array}{l}\text { A holistic appraisal of the partnership based upon a } \\
\text { simultaneous consideration of the above three impact areas. }\end{array}$ \\
\hline
\end{tabular}

\subsection{Questionnaire methods and data calculation}

Based upon a procedure demonstrated by Bai et al. (2010) in the context of urban sustainability experiments in Asia, we applied the above analytical tools to the global sample with both quantitative and qualitative data obtained from two separate questionnaires. The first sought to identify core characteristics and commonalities across the sample. It consisted of a quantitative application of the six-level analytical framework in Table 2. Questionnaires were administered electronically to one key university personnel in each case-in most instances the project leader. Persons were identified from partnership documents such as websites, grant proposals, journal papers and press articles. Data was obtained by explaining 
each level and variable in the framework and asking recipients to assign a numerical value of 0 (not at all relevant), 1 (partly relevant) or 2 (extremely relevant) to signify the relevancy of each and every variable to that particular partnership. Responses were obtained from 67 of the 70 sampled, representing a response rate of $96 \%$. For the three cases from which results were unobtainable, two were discarded from the results analysis. For the other, the lead author's knowledge and familiarity with the partnership sufficed for data generation, enabling its inclusion into the results. Regional and world results for each level in the framework have been calculated firstly by tallying the individual values obtained from each partnership in regards to a particular variable, and dividing this by the total amount of scores possible for that level (i.e. $2 \times n$ ). This has resulted in a percentage score signifying the importance of a particular variable relative to others in that level of the framework, from the perspective of all partnerships combined in that geographical region.

The second questionnaire generated both quantitative and qualitative data for the application of the drivers and barriers framework and self-evaluation tools outlined above. In contrast to the first, it was sent to multiple partners and stakeholders in academia, industry, government and civil society in each case. Efforts were made to ensure that survey results were obtained as equally as possible from all societal sectors involved in that partnership. As in the first survey, potential respondents were identified by analysing project documents. 'Snowball sampling' was also employed by requesting partnerships to recommend suitable external partners and stakeholders. To establish commonly experienced drivers and barriers, the first half of the questionnaire asked respondents to indicate numerically the significance of a variable to their partnership, this time on a scale of 0 (not at all significant), 1 (mildly significant), 2 (very significant) and 3 (extremely significant). Space was also provided for recording qualitative information on drivers and barriers. The second half then asked respondents to evaluate overall partnership functioning and impacts on a five-point Likert scale: -2 (strongly disagree), -1 (disagree), 0 (not sure), 1 (agree) and 2 (strongly agree). Also administered electronically, in total 192 questionnaires were sent out to 66 of the 70 cases. Any partnership with less than 12 months since its official formation was excluded (a total of four) for the reason that it would be unreasonable to evaluate performance at such an early stage. A total of 139 responses (a rate of $72.4 \%$ ) were received from 55 of the 66 cases targeted. After two responses were discarded for data quality reasons, 137 were integrated into the final statistical analysis, at an average of 2.5 responses per partnership. Of these, 60 (43.8\%) came from academic actors, $28(20.4 \%)$ from government, $31(22.6 \%)$ from industry and $18(13.1 \%)$ from civil society. From a regional perspective, this translated to 61 responses for Europe (representing 22 cases), 27 from Asia (for 13 cases) and 49 from North America (for 20 cases).

Measures were taken to prevent partnerships receiving a high number of responses from over-influencing global results. Multiple response values in each partnership were weightaveraged into a mean score for each variable. For the component on drivers and barriers, 
each mean was tallied to give a regional and world total. This was then divided by the maximum world score possible (i.e. $3 \times n$ ). This resulted in a percentage score showing the significance of a particular variable in relation to others, once again from the perspective of all cases combined in that region. For the appraisal on partnership functioning and impacts, individual partnership mean values were tallied and converted into a single global mean score for each variable. In parallel, they were also retained to show the distribution of weightaveraged mean scores from each partnership. 


\section{Key characteristics of university partnerships for urban sustainability}

\subsection{Urban systems}

Results in Table 5 demonstrate that the built environment (81\%), energy, heating or cooling $(74 \%)$ and governance and planning $(71 \%)$ are the three most commonly targeted urban systems by university sustainability partnerships. This tendency to focus on the built environment and energy over human and social systems mirrors a trend identified by Bulkeley and Castan Broto (2012) and Castan Broto and Bulkeley (2013). It would seem that the preoccupation with the built environment and energy (which in many contexts are intertwined systems) is driven by climate change concerns and awareness that substantial GHG emission reductions can be achieved through decarbonisation of these systems. Concerning the widespread targeting of governance and planning structures and processes, Evans and Karvonen (2014) also note that university sustainability partnerships can attempt to advance urban sustainability through collaborative planning and policy making with government and political lobbying or advocacy.

Table 5 Urban systems targeted $(n=68$ cases)

\begin{tabular}{rrrrr}
\hline (\% share of maximum score possible) & Europe & Asia & N. America & World \\
Built environment & 80 & 70 & 88 & 81 \\
Transportation & 64 & 43 & 58 & 57 \\
Energy, heating or cooling & 73 & 77 & 74 & 74 \\
Economy, employment and industrial production & 46 & 60 & 76 & 60 \\
Natural environment or green spaces & 54 & 53 & 74 & 61 \\
Food, agriculture and forestry & 38 & 40 & 48 & 42 \\
Water & 39 & 47 & 60 & 49 \\
Solid waste & 34 & 43 & 40 & 38 \\
Governance and planning & 71 & 57 & 78 & 71 \\
Human and social systems & 66 & 50 & 78 & 67 \\
\hline
\end{tabular}

Other frequently targeted systems on a global level are human and social systems (67\%)-i.e. working, living, consumption and cultural patterns, social and information networks; natural environment or green spaces (61\%); economy, employment and industrial production (60\%) and transportation (57\%). Individual results in Europe, Asia and North America show a high degree of consistency, largely reflecting the world total. Asia is one minor exception where human and social systems results (50\%) are considerably lower than in Europe (66\%) and North America (78\%). This could be explained by the prevalence of techno-centric research and knowledge exchange platforms in Asia, typically involving fewer societal interventions due to a focus on early stage R\&D and formal knowledge production. Solid waste (38\%) food, agriculture and forestry (42\%) and water (49\%) are the least commonly targeted systems for both world and individual region results. We interpret this as a reflection of the urban focus of partnerships. 
It should be noted that the bulk of partnerships simultaneously target several of the urban systems listed in Table $\mathbf{5}$ in attempting to advance the sustainability of a particular location, city or region. As shown in Figure 2, the majority of cases are targeting between four to ten (calculated by tallying the total amount of urban systems scoring a 2 [i.e. 'this strongly applies to our partnership'] in each case). Furthermore, there are four instances of large-scale and ambitious schemes to drive sustainability in all ten of the listed systems. Regarding factors influencing the type and quantity of systems targeted, this would likely be determined by partnership objectives - which are themselves shaped by societal needs and conditions, on one hand, and on the other motivations, strengths and disciplines concerned in the lead institution, department or set of researchers.

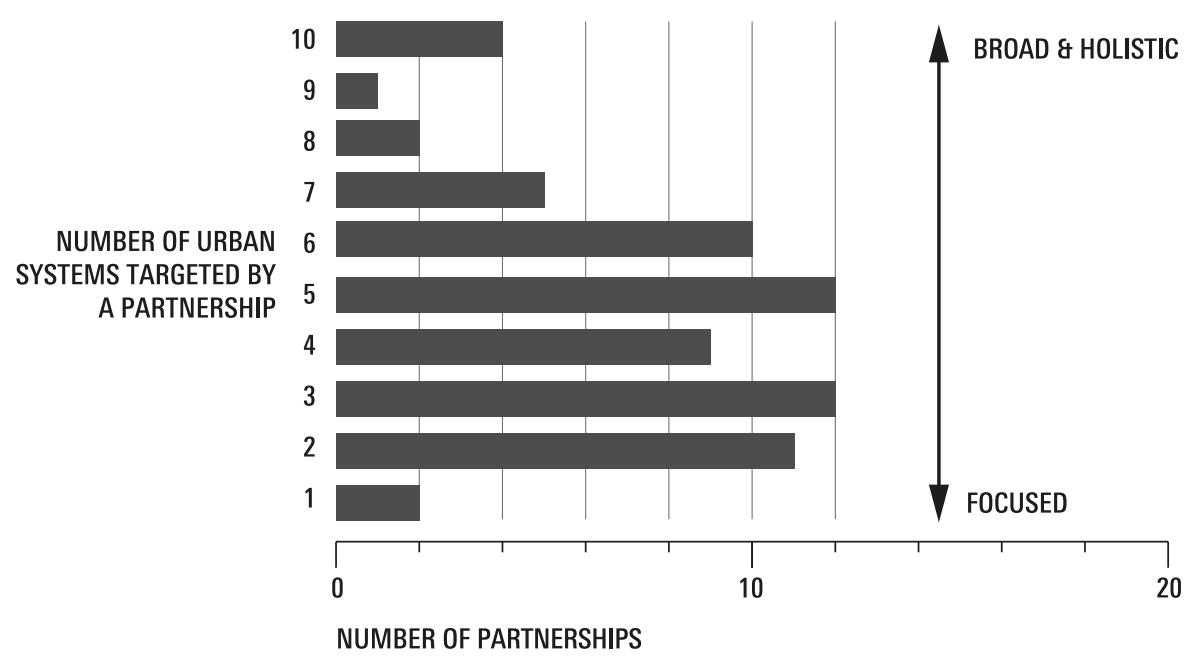

Figure 2 World total for quantity of urban systems targeted ( $n=68$ cases)

\subsection{Geographical scale}

Table 6 shows that the overwhelming majority of partnerships are focused on either the local/neighbourhood level (75\% in Europe, $80 \%$ in Asia and $84 \%$ in North America) or town/city level (69\% in Europe, $90 \%$ in Asia and $88 \%$ in North America. The capacity of the university to utilise scientific knowledge and leverage its various resources to advance urban sustainability thus appears most suited for the scale of individual communities, towns, cities and regions. That said, results also reveal a trans-border focus for several partnerships (21\%) mostly concentrated in Europe (6 cases) and Asia (2 cases). As well as reflecting smaller land-surface areas in these continents compared to North America, such activity at the international scale appears driven by a growing European identity and efforts to spur interEuropean cooperation via government funding. For example, several cases in the European sample such as Sustainable Urban Neighborhoods by Liege University and Hansa Energy Corridor by University of Groningen have been fostered by the Interreg IV programme (financed by the European Regional Development Fund (ERDF) for the period 2007-2013). 
Table 6 Geographical scale of target areas ( $n=68$ cases)

\begin{tabular}{rrrrr}
\hline (\% share of maximum score possible) & Europe & Asia & N. America & World \\
\hline Local/neighbourhood & 75 & 80 & 84 & 84 \\
Town/city & 69 & 90 & 88 & 85 \\
Regional/state & 36 & 63 & 72 & 57 \\
National & 33 & 60 & 22 & 37 \\
Trans-border & 25 & 27 & 8 & 21 \\
\hline
\end{tabular}

The activities of university sustainability partnerships may span multiple geographical scales. Whilst reforming the physical environment and conducting various socio-technical experiments at the local/neighbourhood level or town/city level, many partnerships (e.g. the Oberlin Project by Oberlin College and the 2000 Watt Society Basel Pilot Region by Swiss Federal Institutes of Technology) seek to influence a greater geographical area by exporting experiences and translating research results into regional and national government policy .

\subsection{Internal actors}

As shown in Table 7, the main university actors responsible for the formation, co-ordination and implementation of partnerships are faculty and researchers (96\%) followed by students $(61 \%)$. That said, the presence of the former should be seen as mostly a supporting role, typically taking place through the research rather than educative function of the university. This trend is constant across regional results, with European cases in particular showing a stronger tendency to be driven by faculty and researchers. Results from Europe also indicate that student involvement is overall around half that of Asia and North America. This appears to suggest an unrealised potential for university sustainability partnerships in Europe to function as educational or research enhancing platforms for undergraduate and graduate education, although further research is required on this point.

The active participation of non-academic actors should also be noted. Many partnerships are formed for non-scientific reasons and co-ordinated by actors from administration or bridging organisations such as sustainability or community outreach offices (e.g. NYC Solar American City Partnership by City University of New York and Corridor Manchester by University of Manchester). This reflects the crucial supporting role that administration and bridging organisations can play in urban sustainability collaborations by establishing external contacts and leveraging university resources. 
Table 7 Internal actors types involved ( $\mathrm{n}=68$ cases)

\begin{tabular}{rrrrr}
\hline (\% share of maximum score possible) & Europe & Asia & N. America & World \\
\hline Faculty or researchers & 96 & 100 & 88 & 96 \\
Administration & 48 & 43 & 66 & 54 \\
Students & 34 & 73 & 82 & 61 \\
Bridging organisations & 48 & 57 & 60 & 55 \\
\hline
\end{tabular}

Many partnerships are characterised by internal collaboration between differing sectors of the university (i.e. across disciplines/departments and scientific and non-scientific areas). As

Figure 3 portrays, the majority of cases involve internal collaborations between two, three or even four of the internal actor categories listed in Table 7 (calculated by tallying the total amount of actor types scoring a 2 [i.e. 'this strongly applies to our partnership'] in each case). This testifies that university sustainability partnerships can potentially generate opportunities to link the expertise and activities of varying sectors across the university to specific societal challenges.

NUMBER OF INTERNAL ACTORS TYPES INVOLVED IN A PARTNERSHIP

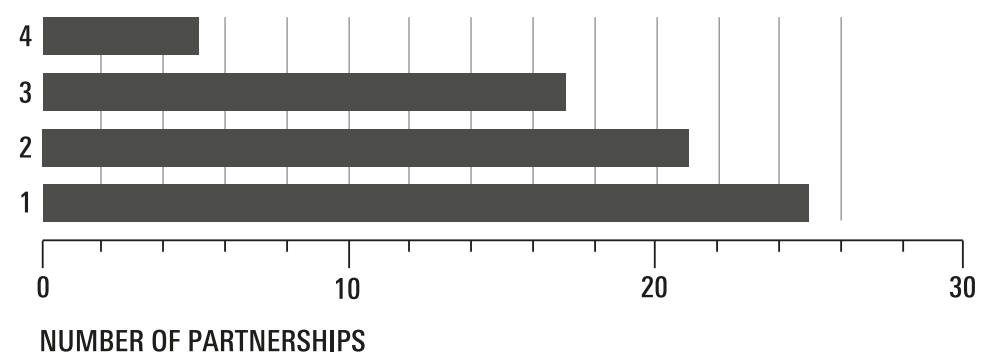

Figure 3 World total for number of internal actor types involved ( $n=68$ cases)

\subsection{External actors}

Table 8 demonstrates that in all three regions local or regional government/public services constitutes the most common external partner for university initiatives to co-design and coproduce urban sustainability. This reflects the earlier observation that the bulk of partnerships are attempting to advance the sustainability of areas corresponding to a local/neighbourhood, city/town or regional level. Evidence from the 70 cases suggest that chief roles for local or regional government may typically entail the integration of scientific research results into policy, planning and legislation (Evans and Karvonen, 2014; Horrigan, 2014); the provision of data, funding and resources such as buildings, vehicles and land to function as test beds; and also core leadership, decision making and public endorsement or promotion of partnerships. Conversely, state or national government is least frequently involved, with a commonly observed and indirect role being the provision of research funds and institutional incentives for cross-sector collaboration. Active participation of civil society (i.e. individual citizens, citizen groups and NPOs etc.) also constitutes another defining characteristic of many university partnerships for urban sustainability. With a score of $48 \%$ in the world total, all but seven cases in Europe, four in Asia and seven in North America involve some sort of civic 
sector collaboration. Also signifying an awareness that civic sector knowledge and engagement is essential for co-producing knowledge, tools and societal transformations for advancing urban sustainability (Mauser et al., 2013; Spangenberg, 2011), key roles assumed by this sector include mutual framing of research questions (Peer and Stoeglehner, 2013), mobilising of community support, political lobbying, provision of specialised knowledge (often through commissioned research), participation in experiments, demonstrations and product design (Keyson et al., 2013) as well as conception and implementation of various projects (Horrigan, 2014; Valkering et al., 2013).

Table 8 External actor types involved ( $n=68$ cases)

\begin{tabular}{rrrrr}
\hline (\% share of maximum score possible) & Europe & Asia & N. America & World \\
\hline Local or regional government/public services & 84 & 93 & 84 & 71 \\
State or national government & 23 & 73 & 38 & 33 \\
Civic society & 38 & 57 & 82 & 48 \\
Other academic institutions & 73 & 53 & 46 & 49 \\
Large or multi-national corporations & 52 & 83 & 28 & 41 \\
Small-medium enterprises & 59 & 57 & 42 & 43 \\
\hline
\end{tabular}

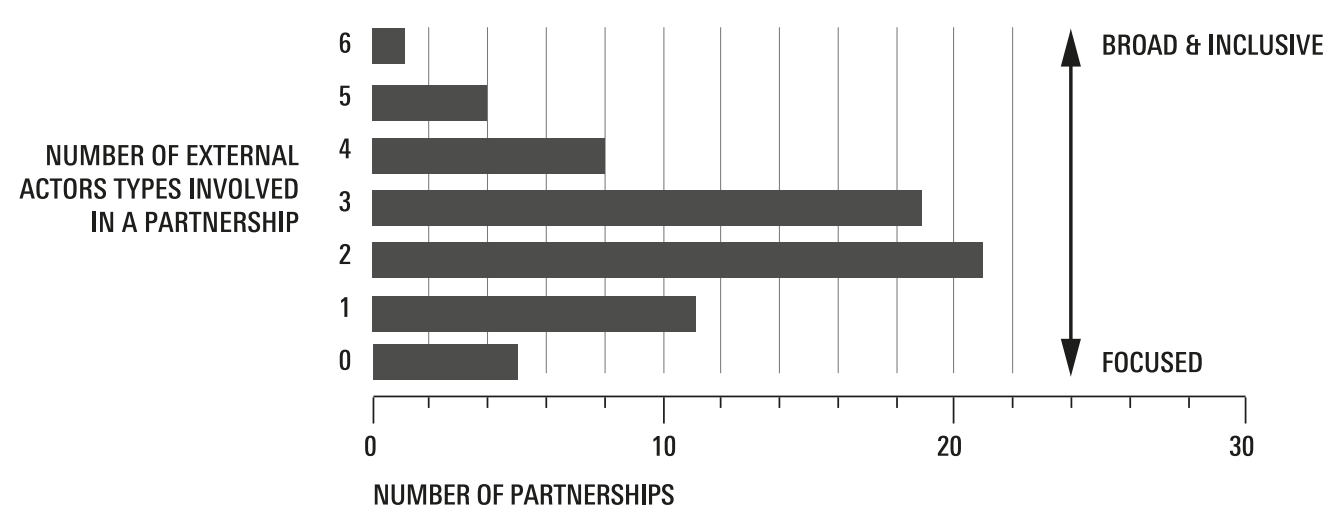

Figure 4 World total for number of external actor types involved ( $n=68$ cases)

Cross-sector sustainability initiatives around the world are also characterised by collaborations between differing academic institutions (typically across differing disciplines). This trend is particularly salient in Europe (73\%). This is undoubtedly mirroring the above observation that many funding programmes in the EU are seeking to foster cross-border cooperation. Findings also indicate that small-medium enterprises (SMEs) can also be involved in the co-design and co-production of urban sustainability. On a global level, the involvement of SMEs (43\%) - which is just as significant as that of large or multi-national corporations $(41 \%)$-reflects commitments from many cases to spur local economic development by fostering new, or supporting existing SMEs (e.g. the Scottish Biofuel Programme by Edinburgh Napier University and the East Bay Green Corridor by University of California, Berkeley). The involvement of large industry is most prevalent in Asia (83\%) and least significant in North America (28\%). Survey evidence suggests that the roles of large 
corporations and SMEs can range from core leadership and decision making; research and development; provision of funding, data, expert knowledge and equipment; and assimilation of co-produced knowledge into products and operations.

Finally, the survey highlights the potential of university partnerships to integrate multiple societal sectors into the co-design and co-production of urban sustainability. Figure $\mathbf{4}$ depicts the number of external actor types from Table $\mathbf{8}$ actively participating in each partnership (as above, calculated by tallying the total amount of actor types scoring a 2 [i.e. 'this strongly applies to our partnership'] in each case). Although a total of 16 partnerships consist of collaborations with a single societal sector or less, the vast majority consists of broad and inclusive alliances between stakeholders from two, three, four or even five categories.

\subsection{Motivations and triggers}

Motivational factors and triggers are listed in isolation in Figure 5 below, although in most cases, several variables apply simultaneously. The two most significant are scientific/scholarly (77\%) and developmental/strategic (77\%). This signifies that the formation of all but five partnerships has been to some extent influenced by the desire to enhance academic knowledge production by engaging with real world situations and translating scientific knowledge into tangible and useful outcomes (i.e. scientific/scholarly motivation). Academic actors seem acutely aware that university research can be enhanced by the codesign and co-production of knowledge and experiments to advance urban transformations towards sustainability. Benefits include enriched learning from real-world settings and interaction between technical and human systems, increased visibility of scientific research and opportunities to export results, as well as the opportunity to supplement theory with application (Keyson et al., 2013; Evans and Karvonen, 2011; Evans and Karvonen, 2014).

The formation of many cases reflects a desire to influence local or regional development trajectories in response to external environmental or socio-economic conditions (i.e. developmental/strategic motivation). For example, some partnerships such as the Oberlin Project by Oberlin College or Verdir by the University of Liege have emerged in reaction to severe and persisting circumstances of post-industrial socio-economic decline. Alternatively, the act of reforming the urban environment and influencing urban development pathways is often driven by motivations of "enlightened self interest" (Dixen and Roche, 2005). This is particularly so for partnerships involving real-estate development such as the Oberlin Project, Corridor Manchester by the University of Manchester and Manchester Metropolitan University, and the Connective Corridor by Syracuse University. 


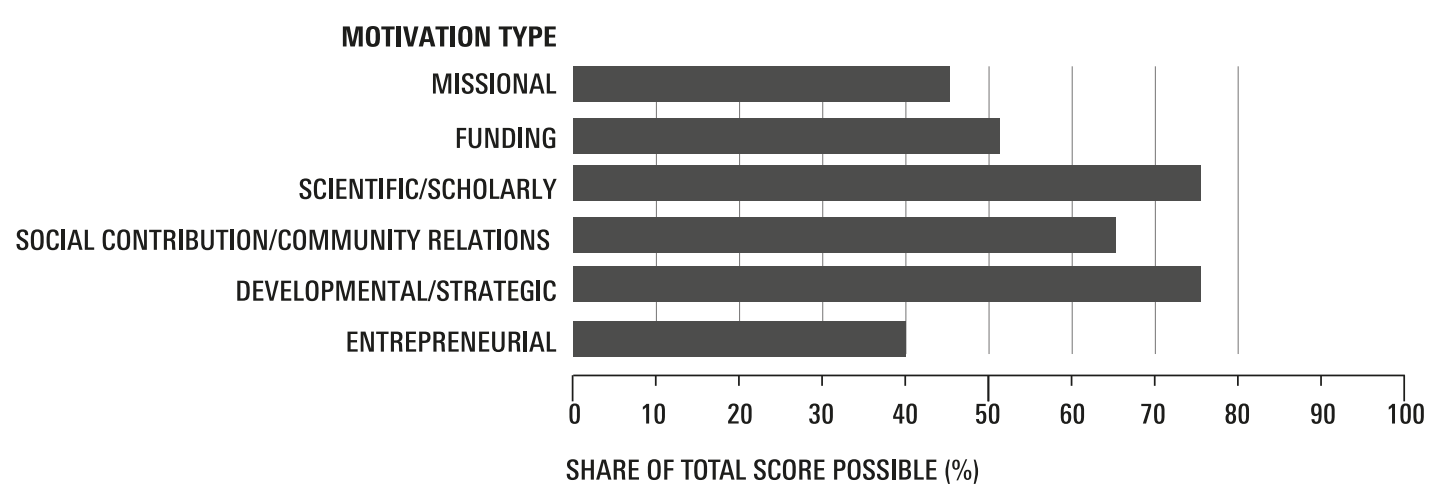

Figure 5 World total for factors motivating partnership formation ( $n=68$ cases)

The funding motivation (54\%) testifies to the potential of funding programmes to foster the formation of cross-sector collaborations for sustainable urban development. Scaling up funding programmes for cross-sector partnerships would significantly increase opportunities for the co-design and co-production of urban sustainability (Dedeurwaerdere, 2013; Trencher et al., 2013; Whitmer et al., 2010). Lastly, results indicate that entrepreneurial motivations (i.e. desires to generate income for any party through technology transfer, venture creation and real estate development etc.) least explain the emergence of most partnerships. Interestingly, this is despite arguments that a so-called 'entrepreneurial paradigm' is transforming scientific conduct and various university functions (Etzkowitz et al, 2000; Etzkowitz and Viale, 2010).

\subsection{Societal engagement modes for co-design and co-production}

Table 9 lists the mechanisms - or societal engagement modes-by which university sustainability partnerships co-design and co-produce urban sustainability. Partnerships are typically characterised by the simultaneous exploitation of multiple engagement modes.

Figure 6, depicting the total amount of actor types scoring a 2 (i.e. 'this strongly applies to our partnership') in each case, indicates that the bulk of partnerships involve activities corresponding with several, in some cases up to five or six, of the engagement modes outlined in Table 9. The exploitation of numerous engagement mechanisms suggests that codesign and co-production can lead to more than just knowledge or policy outcomes. It can also potentially generate new tools and working prototypes of emerging technologies (e.g. hydrogen or electrical mobility solutions in 2000 Watt Society Basel Pilot Region and TUMCreate or energy planning and visualisation tools in Energy Atlas and MEU) social capital building and new socio-technical systems or businesses (e.g. corporate employee carbon reduction schemes in Off4Firms, new urban food systems in Verdir and grass roots participatory public planning in Rust to Green), in addition to transformations of the built or natural environment and interlinked socio-economic and political systems (e.g. real estate and economic development in the Oberlin Project, Corridor Manchester and East Bay Green Corridor). University sustainability partnerships can therefore be viewed as formal representations of numerous, de-centralised initiatives, each embedded in a larger and integrated framework seeking to generate knowledge and advance social, technical and 
environmental transformations.

Across all regions, activities falling into the knowledge management category (i.e. stakeholder consultations, data production and analysis, processing, publication and diffusion of knowledge) are by far the most common (88\% in Europe, 90\% in Asia and 94\% in North America). Despite an ability to perform diverse other functions, the university is first and foremost a place of knowledge production. The significance of knowledge management lies in its ability provide the co-produced intelligence for kick-starting and guiding other mechanisms for advancing sustainability.

Table 9 Societal engagement modes used $(n=68$ cases)

\begin{tabular}{rrrrr}
\hline (\% share of maximum score possible) & Europe & Asia & N. America & World \\
\hline Knowledge management & 88 & 90 & 94 & 90 \\
Governance and planning & 68 & 60 & 78 & 70 \\
Socio-technical experiments & 70 & 87 & 64 & 71 \\
Technical demonstrations and expericents & 48 & 53 & 56 & 52 \\
Technology-transfer or economic development & 48 & 70 & 54 & 55 \\
Reform of built or natural environment & 54 & 63 & 80 & 65 \\
Average number of modes per partnership & 3.0 & 3.3 & 3.2 & 3.2 \\
\hline
\end{tabular}

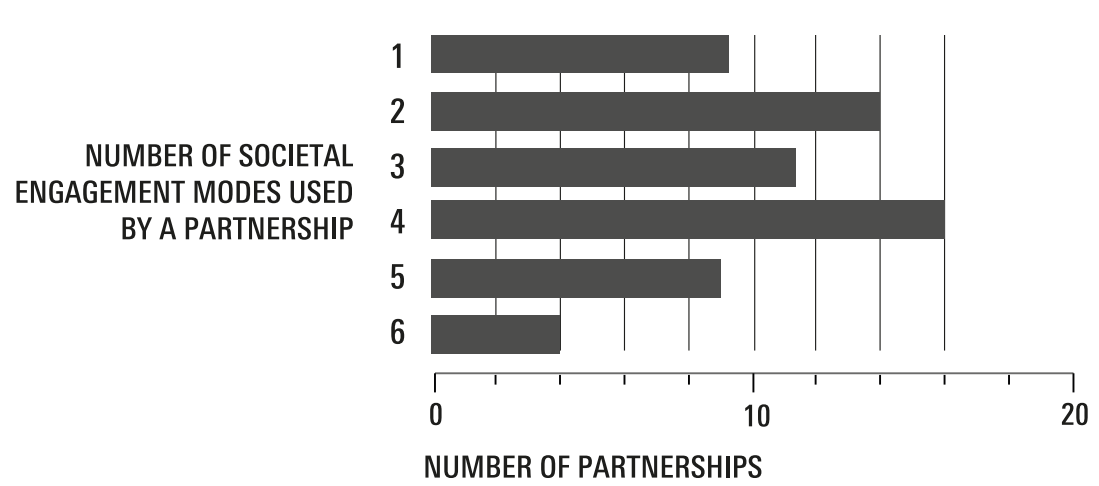

Figure 6 World total for number of societal engagement modes used ( $\mathrm{n}=68$ cases)

Governance and collaborative planning emerged as a significantly commonplace engagement mode ( $70 \%$ world total). Activities such as collaborative planning and policy making with government decision makers, political lobbying and advocacy, and creation of new governance structures and processes are therefore key avenues by which academic actors seek to translate co-produced knowledge into concrete contributions to the advancement of urban sustainability. This tendency also appears to reflect a growing willingness for local and regional government actors to partner with academics when carrying out experimental and self-correcting governance and evidence-based policy making (Bulkeley and Castan Broto, 2012; Evans and Karvonen, 2014). 
The co-design and co-production of urban sustainability through interventions on the physical and natural environment-either scientific or real estate driven-has emerged as highly common in North American settings (i.e. reform of built or natural environment, $80 \%$ ).

Another noteworthy finding is the high prevalence of technical demonstrations and experiments (world $71 \%$ and Asia $87 \%$ ). In contrast, there is a relatively low exploitation of social innovation - as represented by socio-technical experiments (world $52 \%$ ) involving the creation of new configurations of services, technologies, businesses, policies, financial and legal tools and so on. These results signal a global bias towards techno-centric approaches for urban sustainability, a tendency also observed by Castan Broto and Bulkeley (2013). The reliance on technical approaches can partly be explained by a prevalence of R\&D-based platforms headed by faculty and researchers from engineering and the natural sciences. Biases in government funding programmes are also perhaps responsible. The ability of uniquely techno-centric approaches to achieve societal transformations towards sustainability has been shown to be highly limited (Notter et al., 2013). Integration of the social sciences and social innovation are areas requiring more attention and development in future efforts to collaboratively advance the more human dimensions of urban sustainability.

Finally, findings suggest a relatively low exploitation of technology transfer or economic development (world 55\%, Europe 48\% and North America 54\%). This is despite global promotion of this mode of societal engagement through paradigms such as a 'third mission' or 'entrepreneurial university'. The exception is Asia (70\%), where results are influenced by the presence of several $R \& D$ and demonstration platforms in Singapore involving an explicit objective of generating commercialisable research results (e.g. TUM-Create by Nanyang Technological University and the Technical University of Munich, and Sustainable Supply Chain Centre - Asia Pacific collaboration by the University of Singapore). The low overall exploitation of this mode indicates involvement of university actors (both scientific and nonscientific) from outside research-intensive engineering and hard science disciplines where commercialisation of academic inventions is most prevalent. We interpret this as evidence that university initiatives to co-design and co-produce urban sustainability are signifying the emergence of a stakeholder collaboration paradigm moving beyond technology transfer (Trencher et al., 2014; Trencher, 2014). 


\section{Key drivers, barriers, effectiveness and impacts}

\subsection{Drivers and positive factors}

Table 10 shows that the most commonly reported factors assisting partnerships are synergy (86\%) and strong leadership (83\%) - two factors relating to internal project dynamics. This confirms arguments that impacts from innovation and societal intervention efforts can be maximised through the synergistic effect of cross-sector collaboration (Cash et al., 2003; Kania and Kramer, 2011; Whitmer et al., 2010). Yet results also show that the presence of strong individual leaders or 'champions' is a decisive driving factor, as also argued by Lozano (2006) and Zilahy and Huisingh (2009). Qualitative survey responses indicated that strong leaders are able to enhance partnerships by "leading, pushing and driving the collaboration"; mustering external support and recruiting other leaders and change agents; exploiting the full strength, expertise and experience of each partner; and also, instilling a common vision and set of values amongst various partners.

Table 10 Drivers and success factors ( $\mathrm{n}=55$ cases)

\begin{tabular}{rrrrr}
\hline (\% share of maximum score possible) & Europe & Asia & N. America & World \\
\hline Partnership synergy & 82 & 84 & 92 & 86 \\
Strong leadership & 71 & 88 & 93 & 83 \\
External funding & 83 & 84 & 71 & 79 \\
Co-ordination support & 68 & 68 & 83 & 74 \\
Societal 'need' & 69 & 82 & 76 & 75 \\
Positive societal forces (*) & 65 & 68 & 73 & 69 \\
Government policy & 69 & 80 & 63 & 69 \\
University policy (**) & 62 & 51 & 68 & 62 \\
\hline
\end{tabular}

* See Table 3 for definition. ${ }^{* *}$ Based on responses from 63 faculty/researchers

Another significant driver is external funding ( $83 \%$ for Europe, $84 \%$ for Asia and $71 \%$ for North America). Qualitative responses revealed that several cases were 'coerced' into formation by the presence of dedicated funding programmes (e.g. Interreg) aimed at fostering cross-sector efforts to address place-specific sustainability challenges. Qualitative responses reported that the procurement (or prospect of procuring) funding was helpful in securing participation and driving action from private and government partners. Such findings again support arguments that targeted funding programmes can drive place-based sustainability collaborations (Dedeurwaerdere, 2013; Whitmer et al., 2010).

Co-ordination support in the form of devoted project offices, managers and administrators is important for assisting efforts to co-design and co-create urban sustainability. This was particularly so in North America (83\%), as 'backbone organisations' can free project leaders and investigators from administrative duties, allowing them to concentrate on research or implementation activities (Kania and Kramer, 2011). In contrast, university policy has emerged as the most insignificant driver (61\% for Europe, 51\% for Asia and $67 \%$ for North 
America). Both variables signal that the development of internal incentive mechanisms and strategies for fostering change in academic culture (Hoover and Harder, 2014; Lozano, 2006), and supportive infrastructures such as offices and staff, are key areas for consideration.

\subsection{Barriers and negative factors}

Table 11 demonstrates that internal dynamics and project management related factors again dominate the agenda. Time restraints (67\%) and funding (63\%), followed by lack of harmony/unity (58\%) and communication (55\%) constitute the most significant impeding factors. World results largely reflect those for each region, particularly so for time restraints and funding. In connection to the time restraints issue, in accord with findings from Hoover and Harder (2014) it became evident from qualitative responses that university actors and partners typically engage in cross-sector sustainability initiatives in addition to existing job commitments. Although not possible for all partnerships due to limited financial, physical and human resources, the need for dedicated supporting staff and backbone infrastructure such as project offices is evident.

Figure 6 offers a more detailed breakdown of funding barriers, with availability of suitable funding programmes emerging as the central issue. Qualitative responses reported that valuable time is "snatched" from partnership activities if faculty are forced to constantly pursue funding sources, also conveying that inadequate financial resources can reduce the societal impact of projects. This occurs as limited funding blocks are broken down into even smaller packages in the goal of supporting a large portfolio of projects. It was also reported that the absence of adequate funding can impede the securing of key external partners.

Table 11 Commonly encountered drivers and negative factors ( $n=55$ cases)

\begin{tabular}{rrrrr}
\hline (\% share of maximum score possible) & Europe & Asia & N. America & World \\
Time restraints & 61 & 69 & 65 & 67 \\
Funding & 64 & 62 & 59 & 63 \\
Lack of unity/harmony & 66 & 56 & 58 \\
Comminication difficulties & 61 & 57 & 51 & 55 \\
Poor management and leadership & 59 & 53 & 48 & 52 \\
Lack of external support and interest & 54 & 48 & 47 \\
Social, cultural or institutional barriers & 49 & 44 & 33 & 36
\end{tabular}


SPECIFIC FUNDING ISSUE

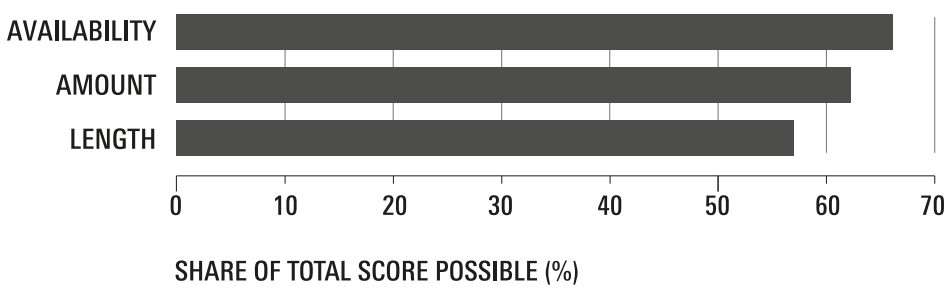

Figure 6 Breakdown of specific results for funding barrier ( $n=55$ cases)

Technical issues are the least significant obstacle in each region, also reflecting results from a survey of 30 sustainability experiments across Asia (Bai et al. 2010). Interestingly, this is despite the earlier-noted bias towards techno-centric approaches and trials of emerging technologies.

Questionnaires included an additional component aimed at university faculty and researchers. This was to assess if commonly reported academic norms and incentive structures such as an emphasis on disciplinary scholarship and tangible outputs such as publications and conference presentations (Hoover and Harding, 2014; Whitmer et al., 2010; Yarime et al., 2012) are impeding the participation of faculty and researchers in cross-sector sustainability efforts. Figure 7 reveals that such barriers are by no means universal. Around half of responses indicate that academic culture is to some extent a barrier, with a total of nine individual faculty/researchers reporting that academic culture is an "extremely significant" obstacle. Findings could be interpreted in two ways. Firstly, in many cases faculty and researchers interested in engaging with external stakeholders on local or regional sustainability agendas will do so, even in the absence of institutional incentives (Hoover and Harding, 2014). Secondly, certain academic settings, disciplines and departments are, contrary to common belief, actually encouraging faculty engagement with real-world sustainability agendas and external stakeholders.

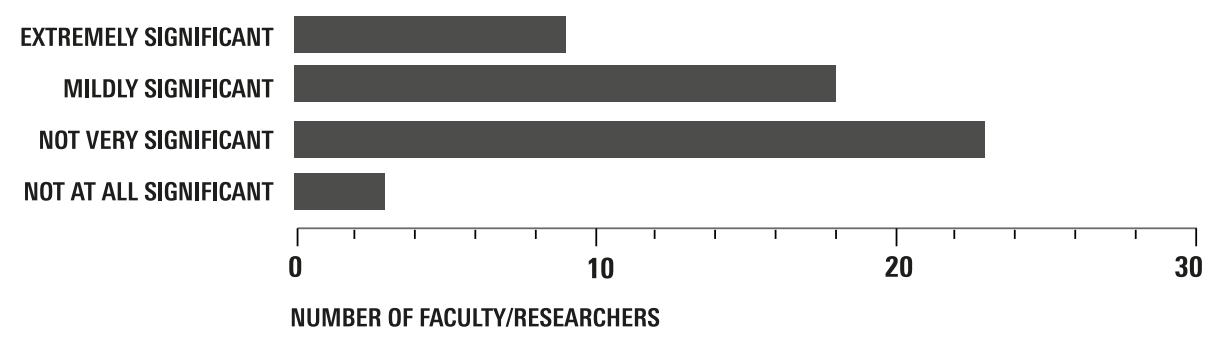

Figure 7 Academic norms and incentives as a barrier (Based on responses from 53 individual faculty/researchers)

Qualitative responses also underscored that differing "worldviews", priorities and planning periods across academia, local government and industry can hinder efforts to co-design and co-produce urban sustainability. A consensus emerged that priorities in local government tend to be focused on short-term rather than long-term planning, which is at odds with the longterm focus of academics dealing with sustainability. Related to this, different decision making 
protocols across sectors also emerged as a key challenge. Government decision making is often lengthy and complex, with industry, on the other hand, tending to arrive at decisions much faster. Again, this is at odds with the slow and deliberate nature by which results are released from the scientific community. Some respondents suggested that the key to overcoming such obstacles is to know and respect the cultures and capacities of the differing players, and to identify and link projects to present government priorities and success criteria. Such issues are to some extent explored in the literature (Evans, 2006; Fadeeva, 2004). Yet further understanding is needed on strategies for overcoming potential tensions and cultural differences when co-designing and co-producing cross-sector sustainability projects.

Lack of unity/harmony barrier was another recurring qualitative theme. A member of the European business community confided that inconsistencies can arise from differing interpretations of project objectives. In this case, "a mismatch between the goal of the project as written in the proposal and what the different partners are considering their goal" had hampered partnership synergy and collective impact. A faculty member in Asia indicated that the cohesiveness and synergy of large-scale sustainability partnerships can deteriorate not only across societal sectors, but also across academic departments and disciplines.

Regarding this, respondents stressed the need for effective project management and communication, as well as articulation of a common vision, motivation and objective in the formation stage.

\subsection{Effectiveness and impacts}

On the functioning of individual partnerships, respondents were asked firstly about synergy and if the participation of different actors and societal sectors had (or is having) a positive effect on partnership activities. Results indicate an overwhelming positive consensus, with a global mean of 1.36 and average scores from 51 of 55 partnerships falling in the range of 1.00 to 2.00 . Scholarly arguments that cross-sector cooperation is vital for advancing sustainability are confirmed by partnership actors working 'on the ground' around the world.

Table 12 Mean and distribution of results for evaluation areas ( $n=55$ cases)

\begin{tabular}{|c|c|c|c|c|c|c|c|c|c|}
\hline Evaluation areas & Mean & {$[-2.00,-1.51]$} & {$[-1.50,-1.01]$} & {$[-1.00,-0.51]$} & ] [-0.50,-0.01] & {$[0.00,0.49][$} & {$[0.50,0.99]$} & {$[1.00,1.49]$} & {$[1.50,2.00]$} \\
\hline Synergy & 1.35 & 0 & 0 & 0 & 0 & 3 & 1 & 24 & 27 \\
\hline Function & 0.84 & 0 & 0 & 2 & 0 & 10 & 9 & 24 & 10 \\
\hline Effectiveness & 0.73 & 0 & 0 & 1 & 4 & 8 & 7 & 31 & 4 \\
\hline Economic & 0.44 & 1 & 0 & 2 & 5 & 14 & 15 & 13 & 5 \\
\hline Environmental & 0.84 & 1 & 0 & 0 & 0 & 8 & 12 & 26 & 8 \\
\hline Societal & 0.82 & 1 & 0 & 0 & 0 & 8 & 13 & 27 & 6 \\
\hline Overall sustainability & 0.90 & 1 & 0 & 0 & 0 & 4 & 9 & 36 & 5 \\
\hline
\end{tabular}


Despite immense faith in cross-sector collaboration, Table 12 portrays that when it comes to translating this potential into actual results (i.e. effectiveness) partnerships can fall short of expectations. With a global mean of 0.76 and scores for several partnerships below zero or in the minus figures, some partnerships were deemed not to have successfully achieved (or not be on track to achieving) initial objectives. This said, mean scores for 34 of the 55 partnerships sampled fell in the range of 1.00 to 2.00 indicating, overall, a moderately strong confidence regarding the effectiveness of individual partnerships.

Respondents were asked to evaluate the impacts (either past or on-going) of the case in question from four dimensions: economic, environmental, societal, and sustainability. Overall, results show the vast majority of cases have been evaluated positively with regard to environment, society and overall sustainability outcomes. Of these, the highest agreement level was for overall sustainability impacts, with a global mean of 0.91 and individual means for 42 of 55 partnerships falling between 1.00 and 2.00. Of note, indicators suggested for each evaluation area in Table 4 were intended as suggestions. Differing individual conceptions of sustainability have undoubtedly influenced the relatively high value of mean scores. Nevertheless, results confirm that the majority of actors surveyed for this studyrepresenting diverse perspectives from academia, industry, government and civil societyhold a positive view of the societal, environmental and overall sustainability impacts attained or likely to be attained by the case in question.

Conversely, Table 12 depicts far less confidence regarding the capacity of cross-sector university partnerships to manifest economic impacts: global mean of 0.47 and mean scores for 36 of 55 cases less than 1.00 . Table 4 shows the indicators loosely suggested for positive economic impacts. These include stimulation of economic activities, creation of employment or a new product/business/service and an increase of regional competitiveness and vitality. Although many partnerships are not explicitly seeking to advance economic development, the triple bottom line approach of sustainability suggests that many would nevertheless manifest positive economic externalities. Our study was unable to determine the precise reasons for this lower confidence regarding economic impacts. However, results call into question the logic of focusing upon economic development as the most desirable means of contributing to society through cross-sector collaborations. Overall, results indicate that university sustainability partnerships are making far more significant impacts towards social, environmental and overall sustainable development-areas in which outcomes cannot easily be measured with conventional economic indicators. 


\section{Conclusion}

This survey of 70 cases gathered evidence from Europe, Asia and North America on a diverse array of university initiatives to co-design and co-produce knowledge and intertwined societal, technological, environmental, political and economic transformations towards greater urban sustainability. Partnerships range from R\&D, knowledge exchange and technology transfer platforms to economic development, real estate and urban reform projects, and urban laboratory experiments, with many being a fusion of these types. Our core objectives were to 1) define attributes such as focus areas, geographical scope, actor types, motivations and mechanisms by which co-design and co-creation of urban sustainability can occur; and 2) identify commonly encountered barriers and drivers whilst assessing functioning and impacts. We have contributed to the literature on university sustainability partnerships in two ways. Firstly, we have created and tested analytical frameworks for conducting systematic and statistical comparisons across a large body of cases. Such tools and approaches were missing until now due to a predominant focus on individual or small sets of cases, with mostly descriptive approaches. Secondly, the international perspective of our study has examined a multitude of university initiatives around the world to collaboratively advance urban sustainability, including non-Anglophone countries, which are typically less prominent in existing scholarship.

Findings indicate that the majority of initiatives are focused on the built environment and energy, but also governance and planning, and human and social systems. Most partnerships are characterised by comprehensive and ambitious attempts to advance simultaneously the sustainability of multiple urban systems, typically unfold at local or city-scales and involve collaborations with local or regional government, often with strong interactions from civil society. University initiatives to co-design and co-produce urban sustainability can potentially provide opportunities for strategic collaboration across differing sectors of the university (both academic and non-academic) and differing institutions. An analysis of motivational factors indicates that partnerships are typically formed to enhance research agendas as well as respond to local or regional challenges and development needs.

Our survey also shed light on key mechanisms for co-designing and co-producing knowledge and societal transformations towards sustainability. Globally, the most common are activities related to knowledge creation, processing and diffusion. A bias towards technical approaches was identified (especially in Asia), with initiatives related to social innovation and the creation of new socio-technical systems significantly less common. This is despite growing evidence that the ability of purely techno-centric approaches to achieve social transformations towards sustainability is highly limited (Notter et al., 2013). The influence of government funding priorities and corporate interests in shaping technology-driven responses to urban sustainability challenges deserves further scrutiny. In many national settings, funding programmes are distinctly privileging fields such as engineering and the natural sciences by 
explicitly associating urban sustainability with the creation and testing of new technologies and intense collaboration with industry. However, widespread use of other partnership mechanisms suggests that potential outcomes of university initiatives to co-design and coproduce urban sustainability need not be limited to new knowledge, technological prototypes or inputs to government policy. They can encompass the creation and trial of new social configurations and socio-technical systems, new businesses, transformations of the built and natural environment, in addition to the enhancement of social capital and resilience.

Findings on commonly encountered barriers revealed that the most frequent are human rather than technical (despite a preponderance of technical approaches) and mostly related to internal partnership dynamics such as time restraints, lack of unity and harmony, and communication difficulties. This suggests a need for strategies to enhance project management and ensure that projects address contrasting priorities and time horizons in academia and local government. Findings also revealed that current academic norms and incentives can potentially hinder some university actors from engaging in placed-based sustainability work with external stakeholders. Also in evidence of this is the finding that internal university policies are yet to prove a substantial driver for sustainability partnerships.

With academic incentive structures encouraging tangible outputs such as publications and conference presentations - and thereby undervaluing efforts to engage with society and tackle place-specific challenges-measures are required to shift such priorities (Crow, 2010; Yarime et al, 2012). University appraisal and performance based research funding systems from national governments could serve as powerful policy instruments, shifting market signals in research and innovation systems (Hicks, 2012) by placing explicit demands on outputs not only to the economy, but also society and the environment. The UK Research Excellence Framework (REF, 2012) testifies to the possibility of allocating competitive research funds based on impacts to the wider economy and society $(20 \%)$, in addition to conventional research outputs $(65 \%)$ and research environments (15\%), with 'impacts' set to account for a greater share in coming years. Not overlooking the resistance provoked by such an approach (Martin, 2011), a key challenge for the UK-REF lies in the development of suitable and subjective indicators and reporting mechanisms for assessing the impacts of research. Based on such experiences, the time has perhaps come for other nations to experiment with integrating societal impact measures into the allocation of competitive research funds. However, our survey results call into question the logic of focusing upon economic development as the most significant indicator of university efforts to co-design and co-create knowledge and societal transformations toward greater urban sustainability. Our findings suggest that, overall, individual partnerships are making strong social, environmental and sustainability impacts, with far less confidence shown for contributions to economic development.

Another important implication for policy derives from the widespread reporting of funding as both a motivational and driving factor for partnership formation-and potential barrier. A range 
of existing funding programmes targeted at the natural sciences, engineering and social sciences could be reformed to demand principles corresponding with sustainability science such as co-design and co-production with diverse external stakeholders, commitment to generating concrete solutions to place-based challenges, interdisciplinarity and most importantly, demonstration of how the proposed research can contribute to a mutual pursuit of economic, social and environmental development. Funding reform could also address the preponderance of techno-centric approaches to urban sustainability. One solution could be to create more favourable funding opportunities for social sciences and humanities in the context of sustainability, preferably in collaboration with engineering and natural sciences.

In closing, the principles of co-design and co-production of sustainability knowledge, solutions and societal transformations are set to receive renewed global attention with implementation of the Future Earth initiative and continued expansion of sustainability science. In this context, our evidence suggests that university partnerships for urban sustainability are potentially key mechanisms for linking global level research and knowledge to place and stakeholder specific contexts and implementation efforts at the local or regional scale. Yet this role need not be limited to research. Collaboratively tackling urban sustainability challenges is generating increased opportunities for long-term societal engagement for non-scientific and administrative sectors of the university. The co-design and co-production of knowledge and societal transformations is providing important opportunities to reconsider the role and relevance of the university in light of urban sustainability challenges. 


\section{References}

Arbo, P. and Benneworth, P. (2007) Understanding the Regional Contribution of Higher Education Institutions: A Literature Review. OECD Education Working Papers, No.9. OECD Publishing, Paris.

Bai, X. (2007) Rizhao: Solar-Powered City. In: State of the World 2007: Our Urban Future. World Watch Institute, Washington, pp. 108-109.

Bai, X., Wieczorek, A. Kaneko, S. Lisson, S. and Contreras, A. (2009) Enabling sustainability transitions in Asia: The importance of vertical and horizontal linkages. Technol. Forecast. Soc. 76, 255-266.

Bai, X., Roberts, B. and Chen, J. (2010) Urban sustainability experiments in Asia: patterns and Pathways. Environ. Sci. Policy 13, 312-325.

Bell, D. (2007) Fade to grey: some reflections on policy and mundanity. Environ. Plann. A 39, $541-554$

Berkhourt, F., Verbong, G., Wieczorek, Raven, R., Lebel, L. and Bai, X. (2010) Sustainability experiments in Asia: innovations shaping alternative development pathways? Environ. Sci. Policy 13, 261-271.

Birch, E., Perry, D., and Taylor, H. (2013) Universities as anchor institutions. J. High. Educ. Outreach Engagem. 17(3): 7-15.

Bok, D. (2003). Universities in the marketplace: the commercialization of higher education. Princeton University Press, Princeton.

Brown, H., Vergragt, P. Green, K. and Berchicchi, L. (2003) Learning for sustainability transition through bounded socio-technical experiments in personal mobility. Technol. Anal. Strateg. 15(3), 315-291.

Bulkeley, H., Castán Broto, V. and Maassen, A. (2011) Governing low carbon transitions. In: Bulkeley et al. (Eds.), Cities and Low Carbon Transitions. Routledge Taylor and Francis Group, London and New York, pp. $29-41$.

Bulkeley, H. and Castán Broto, V. (2012) Government by experiment? Global cities and the governing of climate change. Trans. Inst. Br. Geogr. 38(3), 361-375. 
Bulkeley, H. Edwards, G. and Fuller, S. (2014) Contesting climate justice in the city:

Examining politics and practice in urban climate change experiments. Glob. Environ. Chang. 25, 31-40.

Canaan, J. and Shumar, W. (2011) Structure and Agency in the Neoliberal University. Routledge, New York NY.

Cash, D., Clark, W., Alcock, F. Dickson, N., Eckley, N., Guston, D., Jager, J. and Mitchell, R., (2003). Knowledge Systems for Sustainable Development. Proc. Natl. Acad. Sci. U.S.A. 100(14), 8086-8091.

Castan Broto, V. C. and Bulkeley, H. (2013) A survey of urban climate change experiments in 100 cities. Glob. Environ. Chang. 23, 92-102.

Clark, W. (2003). Urban environments: battlegrounds for global sustainability. Environ. 45(7), 1.

Clark, W. and Holiday, L., (Eds.) (2006) Linking Knowledge with Action for Sustainable Development: The Role of Program Management - Summary of a Workshop. The National Academies Press, Washington DC.

Cortese, A. (2009) Foreword. In: Bardaglio, P. and Putman, B. (Eds.), Boldly Sustainable: Hope and Opportunity for Higher Education in the Age of Climate Change. NACUBO, Washington DC, pp. 1-9.

Crow, M. (2010) Organizing Teaching and Research to Address the Grand Challenges of Sustainable Development. Bioscience 60(7), 488-499.

De Kraker, J., Cörvers, R., Valkering P., Hermans, M. and Rikers, J. 2013. Learning for sustainable regional development: towards learning networks 2.0? J. Clean. Prod. 49: 114122.

Dedeurwaerdere, T. (2013) Transdisciplinary Sustainability Science at Higher Education Institutions: Science Policy Tools for Incremental Institutional Change. Sust. 5, 3783-3801.

Demeritt, D. (2005) The promises of collaborative research. Environ. Plann. A 37, 2075-2082.

Dixen, D. and Roche, P. (2005) In: Perry, D., Wiewel, W. (Eds.), The University as Urban Developer: Case Studies and Analysis. M E Sharpe, New York NY, pp. 268-284. 
Evans, J. (2006) Lost in translation? Exploring the interface between local environmental research and policymaking. Environ. Plann. A 38, 517-531.

Evans, J. (2012) Environmental Governance. Routledge, Oxon.

Evans, J. and Karvonen, A. (2011) Living laboratories for sustainability: Exploring the epistemology of urban transition. In: Bulkely, H., Castan Broto, V. Hudson, M. et al., (Eds.), Cities and Low Carbon Transitions. Routledge, New York, pp. 126-141.

Evans, J. and Karvonen, A. (2014). Give me a laboratory and I will lower your carbon footprint! - Urban Laboratories and the Governance of Low Carbon Futures. Int. J. Urban Reg. Res. 38 (2), 413-430.

Etzkowitz, H., Webster, A., Gebhart, C. and Terra, B. (2000) The future of the university and the university of the future: evolution of ivory tower to entrepreneurial paradigm. Res. Pol. 29, 313-330.

Etzkowitz, H. 2002. MIT and the rise of entrepreneurial science. London: Routledge.

Etzkowitz, H. and Viale, R. 2010. Polyvalent Knowledge and the Entrepreneurial University: A Third Academic Revolution? Crit. Soc. 36(4) 595-609.

Fadeeva, Z. (2004) Promise of sustainability collaboration-potential fulfilled? J. Clean. Prod. $13,165-174$.

Future Earth. (2013) Future Earth Initial Design: Report of the Transition Team. International Council for Science (ICSU), Paris.

Geels, F. (2002). Technological transitions as evolutionary reconfiguration processes: a multilevel perspective and a case-study. Res. Pol. 31, 1257-1274.

Gibbons, M. (1999) Science's new social contract with society. Nat. 402(2), C81-C84.

Gorman, M. (Ed.) (2010) Trading Zones and Interactional Expertise: Creating New Kinds of Collaboration. MIT Press, Cambridge.

Grimm, N.B., Faeth, S.H., Golubiewski, N.E., Redman, C.L., Wu, J., Bai, X., Briggs, J.M. (2008) Global change and the ecology of cities. Sci. 319, 756-760.

Hanleybrown, F., Kania, J. and Kramer, M. (2012) Channeling Change: Making Collective Impact Work. Stanford Soc. Innovat. Rev. 2012, 1-8. 
Hoffman, M. (2011) Climate governance at the crossroads: experimenting with a global response. Oxford University Press, New York.

Kamal-Chaoui and L. Robert, A., (Eds.), (2009) Competitive Cities and Climate Change, OECD Regional Development Working Papers No. 2. OECD publishing, Paris.

Kania, J. and Kramer, M. (2011) Collective Impact. Stanford Soc. Innovat. Rev. Winter 2011, 36-41.

Karvonen, A., Evans, J. And van Heur, B. (2014) The Politics of Urban Experiments: Radical Change or Business as Usual. In: Marvin, S. and Hodson, M. (Eds.) After Sustainable Cities. Routledge, London, pp.105-114 (in press).

Karatzoglou, B. (2013) An in-depth literature review of the evolving roles and contributions of universities to Education for Sustainable Development. J. Clean. Prod. 49, 44-53.

Keyson, D.V., Al Mahmud, A. and Romero, N. (2013). Living Lab and Research on Sustainability: Practical Approaches on Sustainable Interaction Design. In: Augusto, J. C., Wichert, R., Collier, R., Keyson, D., Salah, A. and Tan, A. (Eds.) Ambient Intelligence: Lecture Notes in Computer Science (8309) Springer, Switzerland, p.p. 229-234.

König, A. (Ed.) (2013) Regenerative sustainable development of universities and cities: the role of living laboratories. Edward Elgar, Cheltenham, pp. 1-27.

König, A. and Evans, J. (2013) Experimenting for sustainable development? Living laboratories, social learning, and the role of the university. In: König, A. (Ed.), Regenerative sustainable development of universities and cities: the role of living laboratories. Edward Elgar, Cheltenham, pp. 1-27.

Hodson, M. and Marvin, S. (2009) Cities mediating technological transitions: understanding visions, intermediation and consequences, Tech Anal Strat Manag, 21: 515-534.

Hoover, E. and Harder, M. (2014) What lies beneath the surface? The hidden complexities of organizational change for sustainability in higher education. J. Clean. Prod. (in press). DOI: 10.1016/j.jclepro.2014.01.081

Horrigan, P. (2014) Rust to Green Cultivating resilience in the Rust Belt. In: Bose, M. et al. Community Matters: Service-Learning in Engaged Design and Planning. Earthscan, Oxon and New York, p.p. 167-186. 
Lienin, S., Kasemir, B. and Stulz, R. (2004) Bridging science with application for sustainability: Private-public partnerships in the Novatlantis pilot-region of Basel. Duebendorf, Switzerland: Novatlantis.

Lienin, S., Kasemir, B., Stulz, R. and Wokaun, A. (2005) Partnerships for sustainable mobility: The pilot region of Basel. Environ. 47(3), 22-35.

Lozano, R. (2006) Incorporation and institutionalization of SD into universities: breaking through barriers to change. J. Clean. Prod. 14, 787-796.

Lubchenco, J. 1988. Entering the century of the environment: a new social contract for science. Sci. 279(5350), 491-497.

Martin, B. 2013. The Research Excellence Framework and the 'impact agenda': Are we creating a Frankenstein monster? Res. Evaluat. 20(3), 247-254

McCormick, K. Anderberg, S., Coenen, L. and Neij, L. (2013). Advancing sustainable urban transformation. J. Clean. Prod. 50, 1-11.

M'Gonigle, M. and Starke, J. (2006) Planet U Sustaining the World. Reinventing the University. NSP, Canada.

Molnar, C., Ritz, T., Heller, B. and Solecki, W. (2011) Using higher education-community partnerships to promote urban sustainability. Environ. 53(1), 18-28.

Mauser, W., Klepper, G., Rice, M., Schmalzbauer, B. S., Hackmann, H., Leemans, R. Moore, H. 2013. Transdisciplinary global change research: the co-creation of knowledge for sustainability. Curr. Opin. Sust. Dev. 5(3-5), 420-431.

Mowery, D. (2007) University-industry research collaboration and technology transfer in the United States. In: Yusuf, S. and Nabeshima, K. (eds.) How universities promote economic Growth. The World Bank, Washington DC, pp. 163-181.

Nevens, F., Frantzeskaki, N., Gorissen, N. and Loorbach, D. (2013) Urban Transition Labs: co-creating transformative action for sustainable cities. J. Clean. Prod. 50, 111-122.

Notter, D., Meyer, R. and Althaus, H. (2013) The Western Lifestyle and Its Long Way to Sustainability. Environ. Sci. Technol. 47(9), 4014-4021. 
Nowotny, H., Scott, P. and Gibbons, M. (2001) Re-thinking Science: Knowledge Production in an Age of Uncertainty. Polity, Malden MA.

O'Brian, K., Pelling, A., Patwardhan, et al. (2012) Toward a sustainable and resilient future. In: Field, C., Barros, T., Stocker, D. et al. (Eds.), Managing the Risks of Extreme Events and Disasters to Advance Climate Change Adaptation. A Special Report of Working Groups I and II of the Intergovernmental Panel on Climate Change. Cambridge University Press, Cambridge UK and New York NY, pp. 437-486.

Organisation for Economic Co-operation and Development. (1991) OECD Principles For Evaluation Of Development Assistance. Paris: Development Assistance Committee. www.oecd.org/dac/evaluationnetwork, last accessed November 3, 2013.

Organisation for Economic Co-operation and Development. (2007) Higher education and regions: globally competitive, locally engaged. OECD Publishing, Paris.

Orr, D. (2013) Governance in the Long Emergency. In: State of the World 2013: Is Sustainability Still Possible? Island Press, Washington DC, pp. 279-291.

Pattberg, P, Biermann, F., Chan, S. and Mert, A. (2012) Introduction: partnerships for sustainable development. In: Pattberg, P, Biermann, F., Chan, S. and Mert, A. (Eds.), Publicprivate partnerships for sustainable development: emergence, influence and legitimacy. Edward Elgar, Cheltenham, pp. 1-17.

Perry, D. and Wiewel, W. (Eds.), 2005. The University as Urban Developer: Case Studies and Analysis. M E Sharpe, New York, pp. 268-284.

Peer, V. and Stoeglehner, G. (2013) Universities as change agents for sustainability: framing the role of knowledge transfer and generation in regional development processes. J. Clean.

Prod. 44, 85-95.

Pothukuchi, K. (2011) Building sustainable, just food systems in Detroit: reflections from SEED Wayne, a campus-community collaborative. Sust. 4(4), 193-198.

Reid, W., Chen, D., Goldfarb, L., Hackmann, H., Lee, Y., Mokhele, K., Ostrom. E., Raivio, K., Rockstrom, J., Schellnhuber, H. and Whyte, A. (2010) Earth System Science for Global Sustainability: Grand Challenges. Sci. 330, 916-917.

Research Excellence Framework. (2012) Panel criteria and working methods, http://www.ref.ac.uk/pubs/2012-01, accessed 5 November, 2013. 
Rotmans, J. and Loorbach, D. (2008) Transition management: reflexive governance of societal complexity through searching, learning and experimenting. In: van den Bergh, J.C.J.M. and Bruinsma, F.R. (Eds.), Managing the transition to renewable energy. Edward Elgar, Cheltenham, pp. 15-46.

The Royal Society. (2006) Survey of factors affecting science communication by scientists and engineers.

http://royalsociety.org/uploadedFiles/Royal_Society_Content/Influencing_Policy/Themes_and _Projects/Themes/Governance/Final_Report_-_on_website__and_amended_by_SK_no_navigation.pdf, last accessed January 23, 2014.

Schaffer, D. and Vollmer, D., (Rapporteurs), (2010) Pathways to Urban Sustainability: Research and Development on Urban Systems. Summary of a workshop. National Research Council of the National Academies. The National Academies Press, Washington DC.

Schaffers, H. and Turkama, P. (2012) Living Labs for Cross-Border Systemic Innovation. Tech. Innov. Man. Rev. September, 25-30.

Sedlacek, S. (2013) The role of universities in fostering sustainable development at the regional level. J. Clean. Prod. 48, 74-84.

Shrum, W. Genuth, J. and Chompalov, I. (2007) Structures of Scientific Collaboration. MIT Press, Cambridge.

Smith, A. and Raven, R. 2012. What is protective space? Reconsidering niches in transitions to sustainability. Res. Pol. 41, 1025- 1036.

Spangenberg, J. (2011) Sustainability science: a review, an analysis and some empirical lessons. Environ. Conserv. 38(3): 275-287.

Stephens, J., Roman, G., Graham, A. and Scholz, R. (2008) Education as a Change Agent for Sustainability in Different Cultures and Contexts. Int. J. Sustain. High. Educ. 9(3), 317-338.

Stephens J., Hernandez, M. and Boyle, M. (2009) Learning from University-Community Partnerships (past and present) for sustainable development. In: George Perkins Marsh Institute Working Paper No. 2009-04. Worcester, MA: Clark University, http://www.clarku.edu/departments/marsh/news/workingpapers.cfm, last accessed June 25, 2013. 
Trencher, G., Yarime, M. and Kharrazi, A. (2013) Co-creating sustainability: Cross-sector university collaborations for driving sustainable urban transformations. J. Clean. Prod. 50, 4055.

Trencher, G., Yarime, M., McCormick, K, Doll, C. N. and Kraines, S. (2014) Beyond the third mission: Exploring the emerging university function of co-creation for sustainability. Sci. Public. Pol. 41(2), 151-179.

Trencher, G. (2014) Co-creative university partnerships for urban transformations towards sustainability: Beyond the third mission through technology transfer. PhD dissertation, University of Tokyo.

United Nations Development Programme. (2009) Handbook on Planning, Monitoring and Evaluating for Development Results. http://web.undp.org/evaluation/handbook/index.html, last accessed December 5, 2013.

Valkering, P., Beumer, C., De Kraker, J. and Ruelle, C. (2013) An analysis of learning interactions in a cross-border network for sustainable urban neighbourhood development. J. Clean. Prod. 49, 85-94.

Vorley, T. Nelles, J. (2008) (Re)Conceptualising the academy: institutional development of and beyond the third mission. J. High. Educ. Pol. Manag. 20(3): 1-17.

Whitmer, A., Ogden, L. Lawton, J. et al. (2010) The engaged university: providing a platform for research that transforms society. Front. Ecol. Environ. 8, 314-321.

Yarime, M., Trencher, G., Mino, T., Scholz, R., Olsson, L., Ness, B., Frantzeskaki, N. and Rotmans, J. (2012) Establishing sustainability science in higher education institutions: towards an integration of academic development, institutionalization, and stakeholder collaborations. Sust. Sci. 7(1), 101-113.

S. Yusuf and K. Nabeshima (Eds.) (2007) How universities promote economic growth. The World Bank, Washington DC.

Zilahy, G. and Huisingh, D. (2009) The roles of academia in Regional Sustainability Initiatives. J. Clean. Prod. 17, 1057-1066. 


\section{Appendix 1: Inventory of cases (For online supplement)}

\begin{tabular}{|c|c|c|c|c|}
\hline Name & $\begin{array}{l}\text { Lead academic } \\
\text { institution(s) }\end{array}$ & Target area(s) & Description \& Focus & $\begin{array}{l}\text { Collaboration } \\
\text { period }\end{array}$ \\
\hline \multicolumn{5}{|l|}{ EUROPE } \\
\hline $\begin{array}{l}\text { Blue Green Dream } \\
\text { (BGD) }\end{array}$ & Imperial College London & $\begin{array}{l}\text { FRANCE: Paris, } \\
\text { ENGLAND: London, } \\
\text { NETHERLANDS: } \\
\text { Rotterdam and } \\
\text { GERMANY: Berlin }\end{array}$ & $\begin{array}{l}\text { Four testing sites have been set up } \\
\text { across EU to show benefits of combined } \\
\text { B\&G (water and greenery) management. } \\
\text { Projects aim to improve the urban } \\
\text { environment and boost resilience to } \\
\text { climate change. }\end{array}$ & $\begin{array}{l}2012-n / a \\
\text { Status: ongoing }\end{array}$ \\
\hline $\begin{array}{l}\text { Campus } \\
\text { Sostenibile }\end{array}$ & $\begin{array}{l}\text { University of Milan, } \\
\text { Polytechnic Institute of } \\
\text { Milan }\end{array}$ & ITALY, Milan & $\begin{array}{l}\text { Project to transform entire campus } \\
\text { neighbourhood of both institutions into an } \\
\text { exemplary urban model of quality of life } \\
\text { and environmental sustainability. }\end{array}$ & $\begin{array}{l}2011-\mathrm{n} / \mathrm{a}^{*} \\
\text { Status: ongoing }\end{array}$ \\
\hline City Lab Coventry & Coventry University & $\begin{array}{l}\text { ENGLAND, Coventry } \\
\text { City }\end{array}$ & $\begin{array}{l}\text { Initiative to establishing Coventry City as } \\
\text { a test-bed, incubation hub and } \\
\text { international showcase for low carbon } \\
\text { innovation, with focus in transport, } \\
\text { buildings, IT, green business and high- } \\
\text { tech start-ups. }\end{array}$ & $\begin{array}{l}2011-\mathrm{n} / \mathrm{a} \\
\text { Status: ongoing }\end{array}$ \\
\hline $\begin{array}{l}\text { Corridor } \\
\text { Manchester }\end{array}$ & $\begin{array}{l}\text { University of Manchester, } \\
\text { Manchester Metropolitan } \\
\text { University }\end{array}$ & $\begin{array}{l}\text { UK: Central } \\
\text { Manchester (Oxford } \\
\text { Road) }\end{array}$ & $\begin{array}{l}\text { Urban reform effort to transform built } \\
\text { environment and infrastructure on } 243 \\
\text { hectare strip of Oxford Road to a low- } \\
\text { carbon hub of knowledge driven business } \\
\text { activity, simultaneously generating } \\
\text { economic growth and employment. }\end{array}$ & $\begin{array}{l}2007-n / a \\
\text { Status: ongoing }\end{array}$ \\
\hline $\begin{array}{l}\text { District Future - } \\
\text { Urban Lab }\end{array}$ & $\begin{array}{l}\text { Karlsruhe Institute of } \\
\text { Technology }\end{array}$ & $\begin{array}{l}\text { GERMANY: } \\
\text { Karlsruhe }\end{array}$ & $\begin{array}{l}\text { An experimental living space is being set } \\
\text { up in Karlsruhe to trial technological and } \\
\text { societal innovation from KIT and } \\
\text { transform a downtown quarter into an } \\
\text { arena for sustainable living. }\end{array}$ & $\begin{array}{l}2011 \text { - } 2020 \\
\text { Status: ongoing }\end{array}$ \\
\hline EcoCities & University of Manchester & UK: Manchester City & $\begin{array}{l}\text { Seeks to provide Greater Manchester } \\
\text { with a future scenario based blueprint for } \\
\text { an integrated climate change adaptation } \\
\text { strategy stretching to the year } 2050 \text {. }\end{array}$ & $\begin{array}{l}2008-2012 \\
\text { Status: completed }\end{array}$ \\
\hline Energy Atlas & $\begin{array}{l}\text { Berlin Institute of } \\
\text { Technology }\end{array}$ & GERMANY: Berlin & $\begin{array}{l}\text { Development, application and transfer of } \\
\text { decision making and planning tool for } \\
\text { making comprehensive assessments of } \\
\text { energy demand, energy balancing and } \\
\text { planning, based on a digital 3D model of } \\
\text { Berlin city. }\end{array}$ & $\begin{array}{l}2011-2013 \\
\text { Status: complete }\end{array}$ \\
\hline $\begin{array}{l}\text { GUGLE (Green } \\
\text { Urban Gate } \\
\text { towards } \\
\text { Leadership in } \\
\text { sustainable } \\
\text { Energy) }\end{array}$ & $\begin{array}{l}\text { University of Natural } \\
\text { Resources and Life } \\
\text { Sciences, Vienna }\end{array}$ & AUSTRIA: Vienna & $\begin{array}{l}\text { Project aiming to contribute to citywide } \\
\text { transition of Vienna to a sustainable and } \\
\text { climate resilient city by testing a series of } \\
\text { policies and technologies in districts of } \\
\text { Penzing and Alsergrund. }\end{array}$ & $\begin{array}{l}2011-\mathrm{n} / \mathrm{a} \\
\text { Status: ongoing }\end{array}$ \\
\hline $\begin{array}{l}\text { Hansa Energy } \\
\text { Corridor Energy } \\
\text { Gateway }\end{array}$ & University of Groningen & $\begin{array}{l}\text { GERMANY: North- } \\
\text { western Lower } \\
\text { Saxony, Bremen } \\
\text { NETHERLANDS: } \\
\text { Northern provinces }\end{array}$ & $\begin{array}{l}\text { Project aiming to accelerate the regional } \\
\text { transition of Dutch-German border to } \\
\text { sustainable energy in fields such as } \\
\text { solar, wind and bio-fuels. }\end{array}$ & $\begin{array}{l}2011 \text { - } 2013 \\
\text { Status: complete }\end{array}$ \\
\hline $\begin{array}{l}\text { Innovative City } \\
\text { Program }\end{array}$ & Aalto University & FINLAND: Helsinki & $\begin{array}{l}\text { Programme directing R\&D activities from } \\
\text { Aalto University towards areas of need } \\
\text { identified in the City of Helsinki to ensure } \\
\text { their contribution to sustainable urban } \\
\text { development in the capital region. }\end{array}$ & $\begin{array}{l}2001-n / a \\
\text { Status: ongoing }\end{array}$ \\
\hline Heat and the City & University of Edinburgh & $\begin{array}{l}\text { SCOTLAND, } \\
\text { Glasgow \& Edinburgh }\end{array}$ & $\begin{array}{l}\text { Action-learning research project to } \\
\text { develop blueprint for catalysing } \\
\text { transitions to sustainable district heating } \\
\text { in 'cold climate' cities. }\end{array}$ & $\begin{array}{l}2011-\mathrm{n} / \mathrm{a} \\
\text { Status: ongoing }\end{array}$ \\
\hline $\begin{array}{l}\text { MEU (Innovative } \\
\text { Instruments for }\end{array}$ & $\begin{array}{l}\text { Ecole Polytechnique } \\
\text { Fédérale de Lausanne }\end{array}$ & $\begin{array}{l}\text { SWITZERLAND, La } \\
\text { Chaux-de-Fonds, }\end{array}$ & $\begin{array}{l}\text { Partnership creating IT visualisation tools } \\
\text { to aid monitoring and planning of energy }\end{array}$ & $\begin{array}{l}2009-\mathrm{n} / \mathrm{a} \\
\text { Status: ongoing }\end{array}$ \\
\hline
\end{tabular}


Energy Management in Urban Areas)

Off4Firms

OPTIMISM
Optimising
Passenger
Transport Systems

Plan Vision

Scottish Biofuel Programme

SMARchTrenk

Smart Urban Adapt

SUN Sustainable

Urban

Neighbourhoods

SusLabNWE

(Formerly Living

Lab Project)

Tecovoiturage

TURaS

2000 Watt Society

Basel Pilot Region
ETH Zurich

Coventry University Coventry University Enterprises Ltd)

Johannes Kepler University of Linz Resources and Life Sciences, Vienna

Edinburgh Napier University

ETH Zurich

ausanne, Martigny

et Neuchâtel

SWITZERLAND and EU

EU wide

AUSTRIA: Freistadt

AUSTRIA:

Marchtrenk

EU: (initial pilot in Zurich and London)
University of Liege

Delft University of

Technology

BELGIUM

NETHERLANDS

GERMANY

Meuse-Rhine

Euregion

NETHERLANDS:

Rotterdam,

GERMANY: Goteborg

and Nordrhein-

Westfalen

FRANCE:

1. nationwide

2. Versailles, Saint-

Quentin-en-Yveline

(Fondaterra)

University College Dublin

Swiss Federal Institutes of

Technology (ETH) domain

BELGIUM: Brussels, UK: Dublin, London, Nottingham, Seville, ITALY: Rome, Sofia, SLOVENIA: Ljubljana, NETHERLANDS:

Rotterdam, and Aalborg

SWITZERLAND,
ENGLAND: London,

usage in small towns, for local

government.

An incentive scheme for firms to reduce $\quad 2010-n / a$ energy consumption and GHG emissions Status: ongoing in employee households. Research platform has evolved to a spin-off firm.

$2011-2013$

Research project seeking to contribute to more sustainable and integrated

Status: complete transport system in Europe. Focus on passenger behaviour and developing a modelling technique to visualise new and improved service offerings.

A co-research effort with the Town of Freistadt to clarify and integrate the relationship between spatial planning, energy demand and district renewable energy supplies. Results integrated into urban development and district biomass heating.

Consulting platform to work directly with Scottish SMEs to develop opportunities for the conversion of low value biomass into bioenergy and sustainable fuels.

Project to build a smart district in the town of Marchtrenk in view of becoming a showcase region for all of Austria regarding the handling of energy and resources.

Project to assist European cities with computer aided decision making tools to design urban development pathways towards a low-carbon society.

Participatory action research and multiactor learning alliance to put seven urban neighbourhoods on pathway to sustainability and stimulate a stagnating socio-economic fabric.

A series of model homes have been built or appropriated and integrated into an $R \& D$ and demonstration network for generating and trialling sustainable products and services for European households.

Free car sharing programme created to reduce transit related GHG emissions in national higher education sector and Saint-Quentin-en-Yvelines, outer Paris.

GERMANY: Stuttgart,

Aims to contribute to EU wide transition to sustainability and resiliency by measuring and comparing transition demonstrations from various participating sites and producing a set of strategies and practical tools for other European cities.

Long-term effort to accelerate the transition to a '2000-watt society' and promote sustainable urban development through various projects in Basel, with wider ambition of accelerating nationa de-carbonisation in mobility, buildings and urban development.
$2009-2011$

Status: complete

$2012-2015$

Status: ongoing

2010 - 2011

Status: complete

$2012-2013$

Status: complete

$2009-2012$

Status: complete

$2008-2015$

Status: ongoing

2008 - ongoing

Status: ongoing

2010 - 2016

Status: ongoing

$2001-2017$

Status: ongoing 
Urban Laboratory for Sustainable

Environment

Urban Living Lab: Versailles

Urban Transition

\section{Øresund}

URSULA (Urban

River Corridors

and Sustainable

Living Agendas

Research Project)

Verdir

University of Liege

University of Sheffield

Initiative Gaia

City University of Hong Kong

\section{DHI-NTU Research} Centre

Nanyang Technologica University

(E2S2) Energy and Environmental Sustainability

Solutions for

Megacities

Hong Kong SME

Business

Sustainability

Index

Green Society ICT Life Infrastructure
Shanghai Jiao Tong University National University of Singapore

Hong Kong Polytechnic University

Keio University
ENGLAND: Central

Sheffield (Don River)

NEDEN \&

DENMARK, Øresund

region

BELGIUM, Greater

Liege

HONG KONG:

Various communities

SINGAPORE: Nationwide

CHINA: Shanghai SINGAPORE: Central

HONG KONG Nationwide

JAPAN: Okutama (Tokyo) and Kuribara City (Miyagi-ken)
A test area and urban laboratory network set up in Lahti to study the functioning of urban ecosystems, impacts of building on the environment and associated

knowledge infrastructure. Data built up during project will be integrated into models and planning tools for area.

Collaboration to 1) carry out experiments in areas such as energy efficiency, EV transport, low-carbon urban planning, green jobs and 2) diffuse already completed or ongoing sustainability initiatives into the community and accelerate the transition to sustainable development.

Alliance to promote sustainable growth in the Øresund Region by mobilising municipalities, universities and businesses for cross-border cooperation. Aims to develop cross-border methods and tools for sustainable urban transformation within 1) sustainable planning processes 2) sustainable construction and 3) financing.

Interdisciplinary research platform to understand interaction between Don

River and urban environment. Involved creation of blueprint for reform of built and natural landscape to improve flooding resistance, beautification and land-use.

Socio-economic and research platform to transform industrial waste zones into centres of urban agriculture and aquaculture, stimulating the local economy and creating employment.

Initiative consisting of three components: 1) art exhibition showcasing CUHK's research in environment, energy and sustainability, 2) carbon scheme aimed at schools and NGOs to pursue energy efficiency and carbon reductions and 3 ) public education and awareness raising.

R\&D platform to generate new water knowledge and strengthen the water and environment industry in Singapore via the development of innovative technologies and training of water and environment professionals.

$R \& D$ platform to improve energy recovery from waste and develop system modelling and data management tools to track and mitigate emerging environmental contaminants. Dual testbeds are set up in several locations across Shanghai and Singapore.

Platform to promote the understanding and adoption of CSR as a business model to foster sustainability practices of business sector in Hong Kong and encourage reporting of sustainability practices.

$2012-2014$

Status: ongoing

$2011-\mathrm{n} / \mathrm{a}$

Status: ongoing

$2011-2014$

Status: ongoing

$2008-2012$

Status: complete

$012-n / a$

Status: ongoing

$2012-2018$

Status: ongoing

2007- 2016

Status: ongoing

$R \& D$ and testing platform to contribute to the resiliency and sustainability of two semi-rural communities. Involves development of ICT system to boost home energy efficiency and measure climate change impacts on health and agriculture.
2012- 2017

Status: ongoing

2011- n/a

Status: ongoing

$2010-2015$

Status: ongoing 


Infrastructure
Supporting Project
for Wind Power
Generation
Business in Jeju
Region
Low Voltage Direct
Current Grid
Network

NUS-JTC Industrial
Infrastructure
Innovation (NUS-
JTC I3) Centre

Sustainable Supply
Chain Centre Asia
Pacific

Jeju National University

KOREA: Jeju Island

Nanyang Technological University

National University of Singapore

Singapore National University

Nanyang Technological University

Hong Kong University of Science and Technology

TUM-Create

Technical University of Munich, Nanyang

Technological University

SINGAPORE: Nationwide

1. SINGAPORE
2. Asia-Pacific

SINGAPORE: Western Singapore

HONG KONG: Tung Chung and Sha Tin

Nanyang Technological University

\section{Underwate \\ Infrastructure and Underwater City of} the Future

\section{Urban Design Centre Kashiwa}

Tokyo University

\begin{abstract}
Urban Reformation
Program for the

Realisation of
\end{abstract}

a Bright Low

Carbon Society

\section{NORTH AMERICA}

Alley Regeneration Project (Formerly Austin
University of Texas at

University of Tokyo

JAPAN: Chiba,

Kashiwanoha

USA: Austin, Texas
SINGAPORE:

R\&D and demonstration project to utilise underwater sea space to construct infrastructures such as oil storage facilities or power stations whilst using the topside as reclaimed land.

JAPAN: Chiba-ken City of Kashiwa

An information exchange, education and research platform addressing issues related to environmental, socio-political and urban planning issues in greater Kashiwa City. Brings together academics, citizens, local city authorities and real

Large-scale applied research initiative to design blueprint for low-carbon, elderly citizen friendly community. Involves extensive demonstrations with technical and social innovation. implementation platform to utilise Hong Kong's citywide seawater flushing system to develop energy-efficient and lowcarbon sewage treatment technologies.

Large-scale R\&D and field testing project with focus on developing an electric taxi for Singapore, with potential for application in other tropical mega cities. Collaboration involves all levels of EV taxi transport: from batteries to the car design, extending to citywide infrastructure and traffic control systems. estate developers.

$2004-n / a$ Status: ongoing

2010- n/a Status: ongoing

2011-2016

Status: ongoing

Status: complete

$2010-2015$

Status: ongoing

$2004-n / a$

Status: ongoing

$2011-\mathrm{n} / \mathrm{a}$

Status: ongoing

2010 - 2015

Status: ongoing

$2006-n / a$

Status: ongoing

$2010-2015$

Status: ongoing

Initiative proposes new 'alley flats' as sustainable and affordable housing alternatives for Austin. Involves

development and installation of detached residential units utilising underused alleyways to increase availability of affordable housing.
2005 - n/a

Status: ongoing 


\section{Carbon Solutions \\ New England \\ (Formerly Carbon \\ Solutions New}

England)

\section{Central New \\ England's Green \\ Business Zone}

\section{City Studio \\ Vancouver}

Compact for Sustainable Future

Connective

Corridor

East Bay Green

Corridor

Erie-GAINS

Grand Rapids

Community

Sustainability

Partnership

Green Corridor

lowa Initiative for

Sustainable

Communities

Hampshire

Sustainability) Emily Carr University
University of Windsor

University of New

Clarke University

(Institute for Energy \&

Simon Fraser University

Massachusetts Institute of Technology Harvard University

Syracuse University

University of California, Berkeley

Gannon University

Grand Valley State University

USA: Michigan

Grand Rapids

USA: Pennsylvania Downtown Erie

CANADA: Ontario, Windsor (CanadaUSA border)

\section{Hampshire, New England}

USA: Massachusetts, Worcester

CANADA: British Columbia, Vancouver

USA: New York, Syracuse

USA: California, East San Francisco between the University, government agencies, community organizations and businesses to halt neighbourhood decline and improve the sustainability and prosperity of downtown Erie and campus neighbourhood

Academic-city formed partnership, with over 200 businesses, institutions and organisations mobilised in coalition to revitalise rust-town of Grand Rapids and promote sustainability in diverse areas such as building, economy, energy, food and water, waste and alternative fuels.

Project integrating public art, sustainable technologies, scientific monitoring and public information along two kilometres of roadway at Canada-USA border crossing. With grassroots engagement, members and students engaged in process transforming built and natural environment, infrastructures, energy production and socio-cultural fabric.

USA: Iowa

(Numerous communities including: Anamosa, Burlington, Charles City, Columbus Junction, Decorah, Oskaloosa, Wellman and Dubuque)
Campus-wide service learning programme to enhance the capacity of lowa's rural and urban communities to address various sustainability issues. Students and faculty are partnered with individual communities to identify, design and implement various projects. $2008-\mathrm{n} / \mathrm{a}$ Status: ongoing

$009-n / a$

Status: ongoing

$2011-\mathrm{n} / \mathrm{a}$

Status: ongoing

$2013-n / a$

Status: ongoing

$2005-2016$

Status: ongoing

$2007-\mathrm{n} / \mathrm{a}$

Status: ongoing

$2010-n / a$

Status: ongoing

$2005-n / a$

Status: ongoing

$2003-2011$

Status: complete
2009 - n/a

Status: ongoing 
Nourishing Ontario Wilfrid Laurier University CANADA: Ontario

\section{NYC Solar American City \\ Partnership}

\section{Oberlin Project}

Pecan Street

\section{Demonstration}

\section{PSU/PGE}

Partnership

Retrofit NYC Block by Block

Rust to Green

SEED Wayne

SoMA EcoDistrict

Southeastern

Massachusetts

Council on

Sustainability
City University of New York

USA: Various areas across NYC

USA: Ohio, Oberlin

USA: Texas, Austin (Mueller community)

USA: New York City: Brooklyn

USA: New York, Utica

USA: Michigan: Detroit

USA: Oregon, Portland, South of the Market District

University of Massachusetts at Dartmouth

USA: Southeastern Massachusetts data via smart meters and appliances
Research and knowledge exchange platform to accelerate transition to sustainable, local food systems across Ontario. Focus areas include: sustainable production, land access, community financing and supply management.

Through Solar American City Partnership, a collaboration to accelerate the diffusion of solar energy across NYC grid. Focused on creating solar mapping and zoning tool to determine most effective locations for solar installations. Also involves developing web-based platform to assist residents with permit and funding applications for solar installations.

Ambitious project driven by Oberlin College to rejuvenate the town of Oberlin by transforming it into a prototype of a self-sufficient, prosperous and resilient post-fossil fuel community.

A smart grid and residential behavioural testing platform to collect and analyse from 1000 homes across Texas, the majority of which are concentrated in the Mueller community.

$R \& D$ and demonstration platform to drive green growth in the Portland metro region and trial emerging technologies from PSU and PGE in urban settings.

Programme to help New York property owners in six boroughs exploit state and federal fiscal incentives to weatherise and take measures to increase energy efficiency. Continuation of Retrofit Bedford Stuyvesant project.

Participatory action research effort to connect key stakeholders and generate strategies and projects to trigger Utica's transition from a 'rust town' to a green economy. Focus on built and natural environment, infrastructure and local agriculture.

Effort to collaboratively build sustainable food system on campus and local community of Detroit. Involves studentrun vegetable and herb gardens on campus, weekly farmers market and local produce selling initiatives.

Urban transformation effort targeted at the community surrounding campus. Project has adopted the Ecocities framework developed by local NPO Ecocities to fuse university development needs and a holistic vision of urban sustainability and community revival into a governance and action framework.

$2007-\mathrm{n} / \mathrm{a}$

Status: ongoing

$2010-n / a$

Status: ongoing

$2008-2017$

Status: ongoing

$2008-2009$

Status: complete

$2010-n / a$

Status: ongoing

$2010-2012$

Status: complete

$2010-\mathrm{n} / \mathrm{a}$

Status: ongoing

$2010-\mathrm{n} / \mathrm{a}$

Status: ongoing

$2011-\mathrm{n} / \mathrm{a}$

Status: ongoing

Council to provide education and assistance on sustainability in

Southeastern Massachusetts. Acts as a leadership forum and network to connect, facilitate and coordinate sustainability efforts throughout region with focus on food and agriculture, transportation, energy and natural resources. $2009-n / a$

Status: ongoing 


\begin{tabular}{|c|c|c|c|c|}
\hline $\begin{array}{l}\text { Sustainable City } \\
\text { Year Program }\end{array}$ & University of Oregon & $\begin{array}{l}\text { USA: Oregon, } \\
\text { Gresham, Salem, } \\
\text { Springfield }\end{array}$ & $\begin{array}{l}\text { To drive sustainable community change } \\
\text { in various cities across the state of } \\
\text { Oregon by applying the educational and } \\
\text { research resources of the university to a } \\
\text { city for one full academic year. In this } \\
\text { service-learning programme, } 20-30 \\
\text { courses across several disciplines work } \\
\text { on designing and implementing projects. }\end{array}$ & $\begin{array}{l}2009-\mathrm{n} / \mathrm{a} \\
\text { Status: ongoing }\end{array}$ \\
\hline $\begin{array}{l}\text { Sustainable } \\
\text { Neighborhood Lab }\end{array}$ & Boston University & $\begin{array}{l}\text { Massachusetts: } \\
\text { Boston }\end{array}$ & $\begin{array}{l}\text { R\&D, demonstration and implementation } \\
\text { effort to use the city of Boston as a living } \\
\text { laboratory and test bed for sustainable } \\
\text { urban development. Large focus on } \\
\text { trialling and diffusing smart city } \\
\text { technologies. }\end{array}$ & $\begin{array}{l}2011-\mathrm{n} / \mathrm{a} \\
\text { Status: ongoing }\end{array}$ \\
\hline $\begin{array}{l}\text { University Clean } \\
\text { Energy Alliance of } \\
\text { Ohio }\end{array}$ & University of Toledo & $\begin{array}{l}\text { USA: Ohio } \\
\text { (statewide) }\end{array}$ & $\begin{array}{l}15 \text { member consortium of Ohioan higher } \\
\text { education institutions, government } \\
\text { agencies and enterprises to foster } \\
\text { sustainable development and deployment } \\
\text { of advanced and renewable energy } \\
\text { technologies in Ohio. }\end{array}$ & $\begin{array}{l}2007 \text { - n/a } \\
\text { Status: ongoing }\end{array}$ \\
\hline UniverCity & Simon Fraser University & $\begin{array}{l}\text { CANADA: British } \\
\text { Columbia, Burnaby }\end{array}$ & $\begin{array}{l}\text { New development of mountain top area } \\
\text { on campus grounds into sustainable, } \\
\text { compact and multi-use community for } \\
10,000 \text { residents. Includes residences, } \\
\text { shops and services and school. }\end{array}$ & $\begin{array}{l}1995-\mathrm{n} / \mathrm{a} \\
\text { Status: ongoing }\end{array}$ \\
\hline $\begin{array}{l}\text { Wisconsin } \\
\text { Sustainability } \\
\text { Business Council }\end{array}$ & $\begin{array}{l}\text { University of Wisconsin- } \\
\text { Madison }\end{array}$ & $\begin{array}{l}\text { USA: Wisconsin } \\
\text { (statewide) }\end{array}$ & $\begin{array}{l}\text { Council serving state businesses } \\
\text { interested in sustainability, CSR or } \\
\text { corporate citizenship. Facilitates } \\
\text { information exchange, support and } \\
\text { education to integrate sustainable } \\
\text { business practices. Seeks to build a } \\
\text { collective mass for innovation, cleantech, } \\
\text { alternative energy and sustainability } \\
\text { leadership. }\end{array}$ & $\begin{array}{l}2008-\mathrm{n} / \mathrm{a} \\
\text { Status: ongoing }\end{array}$ \\
\hline $\begin{array}{l}\text { Yale Community } \\
\text { Carbon Fund }\end{array}$ & Yale University & $\begin{array}{l}\text { USA: Connecticut: } \\
\text { New Haven }\end{array}$ & $\begin{array}{l}\text { Initiative targeting low-to-moderate } \\
\text { income homes as part of university } \\
\text { carbon offset initiative. Programme } \\
\text { generates offset credits by installing } \\
\text { programmable thermostats and } \\
\text { conducting weatherisation fits. }\end{array}$ & $\begin{array}{l}2010-\mathrm{n} / \mathrm{a} \\
\text { Status: ongoing }\end{array}$ \\
\hline
\end{tabular}

* (n/a) Information not available 